\title{
The environmental impact of cultural change: palynological and quantitative land cover reconstructions for the last two millennia in northern Poland
}

Article

Accepted Version

Brown, A., Poska, A. and Pluskowski, A. (2019) The environmental impact of cultural change: palynological and quantitative land cover reconstructions for the last two millennia in northern Poland. Quaternary International, 522. pp. 38-54. ISSN 1040-6182 doi:

https://doi.org/10.1016/j.quaint.2019.05.014 Available at https://centaur.reading.ac.uk/84545/

It is advisable to refer to the publisher's version if you intend to cite from the work. See Guidance on citing.

To link to this article DOI: http://dx.doi.org/10.1016/j.quaint.2019.05.014

Publisher: Elsevier

All outputs in CentAUR are protected by Intellectual Property Rights law, including copyright law. Copyright and IPR is retained by the creators or other copyright holders. Terms and conditions for use of this material are defined in the End User Agreement. 


\section{www.reading.ac.uk/centaur}

\section{CentAUR}

Central Archive at the University of Reading

Reading's research outputs online 
3 Heidi B. Babos ${ }^{\mathrm{a}, \mathrm{b}}$, Stuart Black ${ }^{\mathrm{b}}$, Aleks Pluskowski ${ }^{\mathrm{b}}$, Alex Brown ${ }^{\mathrm{b}}$, Megan Rohrssen ${ }^{\mathrm{a}}$, Anthony

$4 \quad$ Chappaz $^{\mathrm{a}}$

5 a Department of Earth and Atmospheric Science, Central Michigan University, Mt. Pleasant, MI,

$6 \quad$ USA

$7 \quad \mathrm{~b}$ Department of Archaeology, School of Archaeology, Geography and Environmental Sciences,

8 University of Reading, Whiteknights, Reading, Berkshire, UK

9 Corresponding author: anthony.c@cmich.edu

11 ABSTRACT

Efforts to study how human activities have influenced the environment since the end of the

13 Roman period to present day are lacking for North Central Europe. Here, we present new lead $(\mathrm{Pb})$

14 isotope data determined from two sediment cores collected from ancient lakes spanning the last

15 1,500 years, located in the Kuyavian-Pomeranian Voivodeship, Poland. Study sites at Radzyń

16 Chełmiński and Rywałd were used to differentiate Pb sources. Radzyń Chełmiński is located in

17 the vicinity of a late Medieval Teutonic Order castle and town, while Rywałd is situated within a

18 relatively pristine area until the $19^{\text {th }}$ century when it became used for agricultural purpose. Core

19 samples were analyzed for $\mathrm{Pb}$ concentration and isotopes $\left({ }^{206} \mathrm{~Pb},{ }^{207} \mathrm{~Pb},{ }^{208} \mathrm{~Pb}\right)$. Bayesian modelling

20 was used to isolate the anthropogenic signal at each site over time. 
For both sites, $\mathrm{Pb}$ enrichment factors relative to titanium (Ti) and upper continental crust

22 values range from 13 to 159. Lead isotopic ratios range from background, pre-anthropogenic local

23 values $\left({ }^{206} \mathrm{~Pb} /{ }^{207} \mathrm{~Pb}=1.31 \pm 0.03 \%\right.$, ${ }^{208} \mathrm{~Pb} /{ }^{206} \mathrm{~Pb}=1.97 \pm 0.04 \%$ ) to anthropogenic values (SW

24 Poland coal, ore, slag ${ }^{206} \mathrm{~Pb} /{ }^{207} \mathrm{~Pb}=1.17 \pm 0.01 \%$, ${ }^{208} \mathrm{~Pb} /{ }^{206} \mathrm{~Pb}=2.09 \pm 0.01 \%$ ). Modeled

25 anthropogenic contribution varies greatly over time, ranging from 14 to 100\%. At Radzyń

26 Chełmiński, modeled anthropogenic $\mathrm{Pb}$ contribution and measured $\mathrm{Pb}$ concentration follow

27 similar trends. However, at Rywałd, from around A.D.1000 to A.D. 1400 these profiles diverge

28 significantly. Our new insights highlight different sources of $\mathrm{Pb}$ from the $12^{\text {th }}$ century to present

29 day: (1) short range agricultural activities from the town, and (2) long range mining activities.

30 Additionally, prior to the $12^{\text {th }}$ century, our data suggest continental anthropogenic activity possibly

31 favored by a warmer climate.

32

33 KEYWORDS

34 Lead - Isotopes - Sediments - Anthropogenic - Sources - Medieval

\section{INTRODUCTION}

Lead $(\mathrm{Pb})$ is a toxic, non-essential, trace element particularly useful for tracking anthropogenic input in environmental archives (e.g. Lanphear et al., 2005). Using Pb isotopes, we

39 can differentiate between anthropogenic (industrial and mining activities, coal and fuel burning;

40 e.g. Cheng and $\mathrm{Hu}, 2010$ ) and natural sources (i.e. natural weathering processes) that release $\mathrm{Pb}$

41 into the environment (Grousset et al., 1994; Thevenon et al., 2011; Zohar et al., 2014); and as a 
42 result, hypothesize on the timing and locations of past human activities (Fagel et al., 2014; Hosono 43 et al., 2016; Zohar et al., 2014).

Three radioisotopes $\left({ }^{206} \mathrm{~Pb},{ }^{207} \mathrm{~Pb},{ }^{208} \mathrm{~Pb}\right)$ are commonly measured for this type of study 45 (Alfonso et al., 2001; Komarek et al., 2008; Reimann et al., 2012). Due to the durations of their 46 half-lives, these isotopes are considered meta-stable in geologically recent sediment (e.g. Russell 47 and Farquhar, 1960). There are no known environmental or industrial processes that fractionate $48 \mathrm{~Pb}$ isotopes, and thus the isotopic composition of $\mathrm{Pb}$ is affected by $\mathrm{Pb}$ source and geologic location 49 (Cheng and Hu, 2010; Doe, 1970; Flegal and Smith, 1995). Additionally, Pb is relatively stable within the sediment column and not readily susceptible to remobilization by early diagenetic 51 processes or biological activities (Audry et al., 2011; Gallon et al., 2004; Harlavan, 1998; Huerta52 Diaz, 1998; McIntyre and Gueguen, 2013; Schultz et al., 1987; Tessier et al., 1996). By analyzing 53 ratios of these three isotopes: ${ }^{206} \mathrm{~Pb} /{ }^{207} \mathrm{~Pb}$ and ${ }^{208} \mathrm{~Pb} /{ }^{206} \mathrm{~Pb}$, it is possible to assess how source 54 contributions of $\mathrm{Pb}$ have changed over time for a given location (Baron et al., 2006; Harlavan et 55 al., 2010; Zohar et al., 2014).

Within the environment, $\mathrm{Pb}$ isotope ratios may be influenced by local, regional, or global

57 sources (e.g. Choi et al., 2007, Martinez Cortizas et al., 2002, 2016, Mil-Homens et al., 2013, 58 2017). For example, In the Iberian Peninsula a number of studies have used $\mathrm{Pb}$ isotope ratios to 59 document evidence of regional metallurgy and mining from the Chalcolithic ( 3000 BC) to 60 modern period (last 200 years; Martinez Cortizas et al., 2002, 2016, Mil-Homens et al., 2013). In 61 marine sediment within the Portuguese Margin, $\mathrm{Pb}$ isotope ratios were also able to record Roman 62 and modern mining activities from the adjacent Iberian region (Mil-Homens et al., 2017, (Include 63 examples from above refs.) Global signatures from atmospheric transport and deposition of $\mathrm{Pb}$, 64 such as Saharan dust storms, and leaded gasoline emissions in modern times, has also been 

documented (e.g. Bi et al., 2017, Mil-Homens et al., 2017, Shotyk et al., 1998). For this study, regional sources are defined as mining of coal ore, smelting, and leaded gasoline exhaust.

67 Historical mining activities 300 to $500 \mathrm{~km}$ to the southwest of the study site may have introduced

$68 \mathrm{~Pb}$ to the atmosphere, allowing for transport downwind to the study site. This $\mathrm{Pb}$ transported over 69 long range is deposited, via association with sinking particles, in lake and peat sediments (e.g. 70 Novak et al., 2003). Local sources, on the scale of kilometers or less, can also contribute to $\mathrm{Pb}$ 71 enrichments and/or changes in the $\mathrm{Pb}$ isotope ratios in sediments. They include enhanced 72 weathering and erosion of the surrounding landscape due to agricultural activities, building 73 development, metalwork, and domestic coal burning.

Regional patterns of $\mathrm{Pb}$ transport are of particular interest in Poland due to Poland's unique 75 climatic signal in comparison to the rest of Europe, which is sensitive to both oceanic and 76 continental influences (e.g. Zamoyski, 1987). Specifically, the Medieval Warm Period (MWP) 77 ended in Poland earlier than the rest of Europe (Medieval Warm Period: MWP; A.D. 800 to 1300; 78 e.g. De Vleeschouwer et al., 2009a). The portion of the MWP that influenced Poland is known as 79 the Climatic Optimum in Poland (COP, A.D. 800 to 1150; e.g. Pluskowski, 2013). These climatic 80 patterns may have played two non-mutually exclusive impacts on anthropogenic $\mathrm{Pb}$ contributions:

81 directly by impacting efficiency of atmospheric $\mathrm{Pb}$ long range transport from mining regions, and 82 indirectly through changes in human activity at the vicinity of our study sites associated with these 83 climatic changes. Historical $\mathrm{Pb}$ contamination associated with mining activities in Poland has been 85 documented. The Rudawy Janowickie Mountains of Silesia, in Southwestern Poland were heavily 86 mined for coal, copper $(\mathrm{Cu})$, iron $(\mathrm{Fe})$, silver $(\mathrm{Ag})$, and zinc-lead $(\mathrm{Zn}-\mathrm{Pb})$ ores (e.g. Cabala et al., 87 2013; Kierczak et al., 2013; Rybicka, 1996). There is historical documentation of ore mining since 
88 the $12^{\text {th }}$ century, but there may have been mining activity as early as the $5^{\text {th }}$ century A.D.

89 (Ciarkowska et al., 2016; Kierczak et al., 2013; Kylander et al., 2005; Tyszka et al., 2012). Mining

90 activities were recorded as $\mathrm{Pb}$ isotopic ratios and other trace element concentrations in Baltic Sea

91 sediment from the $12^{\text {th }}$ to $17^{\text {th }}$ century A.D. (Zaborska, 2014), and in a bog located in Northern

92 Poland (De Vleeschouwer et al, 2009a, b) from the $9^{\text {th }}$ to $18^{\text {th }}$ century A.D.

Previous studies throughout Europe measured $\mathrm{Pb}$ isotopes in lake and bog sediment to

94

95

96

97

98

99

100

101

102

103

104

105

106

107

108

109

110

estimate the importance and origin of anthropogenic Pb (e.g. Martínez Cortizas et al., 2002).

Sedimentary records from lake and wetland systems act as environmental archives for local and regional anthropogenic activity over time. Ideal study sites for differentiating between local and regional, anthropogenic and non-anthropogenic $\mathrm{Pb}$ sources comprise at least two nearby locations: one rural (relatively pristine) and a second that was influenced by documented human activities. Previous results obtained from sedimentary cores using Pb isotopes from A.D. 500 (post Roman period) to around A.D. 1800 (pre-Industrial Revolution) focus on Western and Central Europe. The few previous studies based to the east of Germany analyzed sediment samples from mountainous regions (Monna et al., 2000; Shotyk, 1998; Véron et al., 2014) and the Baltic Sea (Zillen et al, 2012). Only one study in Northern Poland aimed to track solely regional signals of coal and mining from Southwest Poland (De Vleeschouwer et al., 2009b).

No known high temporal resolution data has been previously published for $\mathrm{Pb}$ isotopes in the Kulmerland region. The main objective of this research was to quantify anthropogenic $\mathrm{Pb}$ pollution over the last 1,500 years at Radzyń Chełmiński, using primarily $\mathrm{Pb}$ isotopic signatures. By comparing similar cores from two nearby sites (one in a rural area and a second in the vicinity of a town), we investigated short range (activity from a surrounding town) versus long range (mining signal from Southwestern Poland) transport pollution, as well as potential indirect climatic 
111 impacts on human development. Our combination of historical context with detailed geochemical

112 data provide new insights about the extent of local and regional pollution dispersal.

113

114 2. METHODOLOGY

$115 \quad \underline{2.1}$ Study Sites

116 Two distinct ancient lake systems within the Chełmo Land, Kuyavian-Pomeranian

117 Voivodeship, Poland were sampled for this study: Radzyń Chełmiński and Rywałd (Figure 1). The

118 Kuyavian-Pomeranian Voivodeship lies along the border of historic Prussia and Poland. It came

119 under Polish control from the mid-10th century and was at the frontier between Polish and Prussian

120 territories. There were increasing raids by Prussians into the 12 th and early 13 th century in

121 response to attempts by Poland to conquer Prussian territories, and eventually Konrad I Duke of

122 Masovia invited in the Teutonic Order to help defend his territories in the early 1230s - with the

123 first timber fortification built at Radzyn in 1234. Historical texts and archaeological studies

124 indicate human settlement from the end of the Roman period (around 300 A.D.) to present (e.g.

125 Pluskowski, 2013). The wetlands, including the Castle Lake, are now largely infilled and covered 126 in sedges, with surface water present to ca. 10-20 cm within the interior of the lake, mostly during 127 the wet winter/spring months.

129 Order castle built between 1310 and 1340 A.D., and a town of approximately 2,000 inhabitants, 130 settled in concurrence with the settlement of the Teutonic Order (early 13th century; Brown et al., 131 2015). The castle remained an important commander center into the 15th century, but was 
132 dissolved in 1454 during the Thirteen Years War (1454-1466). By the 16th century much of the 133 western wing of the castle was a disused ruin. The castle was partly dismantled in the 19th century.

134 Rywałd, located $7 \mathrm{~km}$ due East of Radzyń Chełmiński, is a rural site with evidence of 135 woodland, and minor human impact within the pollen record of the same core during the 11th to 136 12th centuries (Brown et al., 2015). The surrounding area only was used within the past century 137 for agricultural purposes (Brown et al., 2015). The Vistula and Drwęca rivers are in proximity to 138 both sites. The Vistula River runs through the center of the Voivodeship which was once the 139 frontier zone between Slavic Pomeralia (East Pomerania), Prussian Pomesania, and Piast Poland 140 (Brown and Pluskowski, 2011; Pluskowski, 2013; Zamoyski, 1987). The underlying sediment is 141 made up of glacial till deposited by the Scandinavian ice sheet during the Vistulian (Weichselian) 142 Glaciation (receded 11,700 years ago; Marks, 2012).

\section{$144 \quad \underline{2.2}$ Sampling}

146 collected in August 2013 from the center of each wetland basin using a Russian auger. The

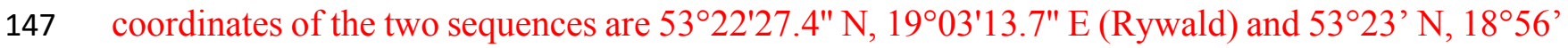

148 E (Radzyn). Sampling intervals were adjusted to obtain high-resolution records during the 149 Crusading Period and Teutonic Order occupation focused on the late medieval period (13 th $16^{\text {th }}$ 150 centuries) based on age models derived from radiocarbon dating. For Radzyń Chełmiński and 151 Rywałd, 60 and 59 samples were considered, respectively. In March 2014, "background” samples 152 of glacial sediment at 100-200 cm depth below land surface were collected adjacent to both lakes 153 using a gouge auger to provide the natural background signature for each site. Four background 
154 samples for Radzyń were collected at Golebiewko, including 6 subsamples (N 53 degrees 23'39.

155 7" E 018 degrees 59'31. 1"). Three background samples for Rywałd were collected in Rywałd, 156 including 9 subsamples (N 53 degrees 20'58.5" E 019 degrees 05'22.0"). All samples were stored 157 at $4^{\circ} \mathrm{C}$ prior to analysis.

\subsection{Analyses}

Sediment cores were logged to determine macroscopic lithofacies. Mastersizer Laser analysis was used to specify particle size within each macro layer. Samples were collected every

$16210 \mathrm{~cm}$ for each lithofacies section. Samples were placed on a plastic crucible where a minimal amount of Calgon solution was added and mixed into sample with a rubber stamper until all

164 particles were separated. All organic material and particles above $2 \mathrm{~mm}$ were removed. The 165 solution was washed with ultra-pure water into the Mastersizer Laser for analysis.

167 with mortar and pestle prior to digestion. Aliquots of $500 \mathrm{mg}$ for each sample were transferred to 168 digestion tubes and cold digested at room temperature for 12 hours using $10 \mathrm{ml}$ ultra-high purity $\mathrm{HNO}_{3}$ under clean lab conditions. Tubes were moved to hot baths and heated at $60^{\circ} \mathrm{C}$ for three

170 hours, then at $110^{\circ} \mathrm{C}$ for an additional 12 hours. We wanted to extract metal deposition from the 171 sediments bound to organic matter, metal that had adhered to particles as a result of atmospheric 172 deposition and metals and elements bound to sediment surfaces. We did not want to digest all the 173 inorganic, silicate material as this leads to a much more complex $\mathrm{Pb}$ isotope signal with the 174 potential to mix from multiple geological sources. Studies have shown (Cook et al. 1997) that hot 175 HNO3 digestion delivers similar results to other digestion techniques as the bulk of the metal 
176 concentration is absorbed to the mineral surfaces and/or in organic matter, not in the mineral

177 silicate components. Digested samples were filtered using a $0.45 \mu \mathrm{m}$ filter and diluted to $100 \mathrm{ml}$

178 in ultra-pure water for analysis.

180 for all analyses. In order to quantify the recovery rates from our digestion methods we used an 181 internal sewage sludge standard normalized against an international standard (ERM CC144), 182 which has reported values for extractable metals in sewage sludge. The reason we chose these 183 standards is that they have reported values for both total digestion and extractable metals (using 184 nitric acid), and have relatively high TOC (36 wt \%) which was similar to the peaty, organic 185 sediments from the core materials. The reported values for our internal standard (normalized to 186 ERM CC144) for $\mathrm{Pb}$ were $118 \mathrm{mg} / \mathrm{kg}$ and $8.8 \mathrm{mg} / \mathrm{kg}$ for Ti. The average of our extracted values 187 over four runs $(\mathrm{n}=8)$ were $128+/-13 \mathrm{mg} / \mathrm{kg}$ and $9.7+/-2.1 \mathrm{mg} / \mathrm{kg}$ for $\mathrm{Pb}$ and Ti respectively, 188 resulting in a recovery of $108+/-9 \%$ and $111+-18 \%$, respectively. This indicates that the nitric 189 acid extraction used was capable of liberating all of the available metal components in the organic 190 fraction.

192 Coupled Plasma - Optical Emission Spectrometer (ICP-OES) at the University of Reading, UK. 193 For each depth horizon, the enrichment factor (E.F.) for $\mathrm{Pb}$ was calculated using the equation (1) 194 provided below (Gloaguen and Passe, 2017; N'guessan et al., 2009) and average upper crustal Pb 195 and Ti concentrations (McLennan, 2001). Enrichment Factor quantifies the amount of enrichment 196 of Pb from natural levels within sediment (e.g. Chester and Stoner, 1973, N'guessan et al., 2009):

197

$$
E F=\frac{\left(\frac{P b}{T i}\right)_{\text {sample }}}{\left(\frac{P b}{T i}\right)_{\text {upper continental crust }}}
$$


To determine $\mathrm{Pb}$ isotopic compositions, digested samples were further diluted to $4 \mathrm{ppb}$ of $\mathrm{Pb}$ for each sample, based on individual $\mathrm{Pb}$ concentrations per sample as quantified by ICP-OES, to maintain the same concentration throughout samples. This was done so that $\mathrm{Pb}$ concentration 201 would not affect Pb isotope analysis. Reference NIST SRM 981 was used as the external standard 202 for ${ }^{206} \mathrm{~Pb},{ }^{207} \mathrm{~Pb}$, and ${ }^{208} \mathrm{~Pb}$ measurements. All analyses were run in bracket configuration (standard-

203 sample-standard) to allow for mass drift correction. Three $\mathrm{Pb}$ isotopes, namely ${ }^{206} \mathrm{~Pb},{ }^{207} \mathrm{~Pb}$, and $204{ }^{208} \mathrm{~Pb}$, were analyzed via Inductively Coupled Plasma - Mass Spectrometer (ICP-MS) 205 (ThermoFisher iCapQ) equipped with a collision cell. The external calibration standard NIST SRM 206981 was used to allow for mass drift correction. The mass drift for ${ }^{206} \mathrm{~Pb} /{ }^{207} \mathrm{~Pb}$ and ${ }^{208} \mathrm{~Pb} /{ }^{206} \mathrm{~Pb}$ were 207 routinely $<0.5 \%$. Two $\mathrm{Pb}$ isotope ratios were calculated: ${ }^{206} \mathrm{~Pb} /{ }^{207} \mathrm{~Pb}$ and ${ }^{208} \mathrm{~Pb} /{ }^{206} \mathrm{~Pb}$. These ratios 208 have been the most widely used in similar studies to determine anthropogenic inputs (e.g. Alfonso 209 et al., 2001, Bi et al., 2017, Díaz-Somoano et al., 2009, Monna et al., 2000,).

\section{$\underline{\text { 2.4 Sediment Dating }}$}

Accelerator Mass Spectrometry (AMS) ${ }^{14} \mathrm{C}$ dating was used to determine absolute age and 213 accumulation rates of sediment. Twelve samples were processed for Radzyń Chełmiński, at $10 \mathrm{~cm}$ 214 intervals, with 10 samples taken from Rywałd, at 5-15 cm intervals. Samples for radiocarbon 215 dating were sent to the Scottish Universities Research Centre (SUERC), Glasgow, Scotland. Linear 216 regression modelling was conducted using Bayesian accumulation to provide age-to depth 217 estimations through each core (SI_1; Bacon; Blaauw and Christen, 2011). To represent sediment 218 dates, the notation "A.D." was used for the age. 

lakes and peat bogs. Terrestrial plant macrofossils are considered the most reliable material for

221 radiocarbon dating (Blaauw et al 2004), although unfortunately none were recovered from either

222 Radzyń or Rywałd. Radiocarbon dates were therefore derived on samples of gyttja (Radzyń) and

223 in the case of Rywałd on both peat and gyttja. Care was taken to identify any potential issues of

224 contamination with old or young. Contamination by young carbon may occur through root 225 penetration, whilst lake sediments may exhibit older radiocarbon ages (reservoir effect) reflecting 226 inclusion of old carbon eroded from calcareous soils/bedrock, or through the uptake of dissolved 227 inorganic carbon by aquatic plants (Björk and Wohlfarth 2004; Butz 2017).

Samples of bulk peat from Rywałd are derived from herbaceous fen considered reliable material for radiocarbon dating (e.g. Nilsson et al 2001; Blaauw et al 2004). The peat deposits 230 reflect treeless habitats, although some herbaceous plants growing in fens, such as sedges, have 231 root systems which can penetrate down to $2 \mathrm{~m}$, with the potential to introduce young carbon unless 232 removed (e.g. Valiranta et al 2014). However, no roots or evidence for rooting by either trees or 233 herbaceous plants was recorded during the detailed examination and sampling of the cores. The core from Radzyń was the final of three cores (Radzyń 3) sampled and analysed from 235 the Castle lake, with dates derived on gyttja (Radzyń 2 and Radzyń 3) and in the case of the first 236 Radzyń core (Radzyń 1) on both peat and gyttja. Although the occurrence and/or magnitude of a 237 reservoir effect can be difficult to determine without supporting dates from plant macrofossils or 238 lake varves, comparison between the four lake sequences from Radzyń and Rywałd suggest that if 239 present at all, the reservoir effect had a negligible effect on the chronologies. All four sequences 240 show a strong linear progression in radiocarbon dates. There is a high degree of temporal similarity 241 in pollen signals between sites, irrespective of whether dates are derived from peat or gyttja. 
242 Similarity is apparent in the timing of key changes in vegetation and land-use, most apparent in

243 the decline in hornbeam, and the onset of major anthropogenic activity from c. AD 1100 (Brown

244 2019); these changes are considered to reflect comparable local-regional processes, reflected with

245 varying magnitude in all four sequences from Radzyń and Rywałd. One could reasonably expect

246 to observe spatial and temporal variations in the magnitude of a reservoir effect, reflecting

247 variation in carbon input within and between sites and pollen sequences as a result of lake

248 catchment, vegetation and land-use (e.g. Tranvik et al 2009; Shou et al 2015) The high degree of

249 similarity therefore argues against a significant reservoir effect at Radzyń and Rywałd.

250

251

$\underline{2.5}$ Modelling

The Bayesian mixing model Food Reconstruction Using Isotopic Transferred Signals

253 (FRUITS; Fernandes et al., 2014) was run with our $\mathrm{Pb}$ isotope data $\left({ }^{206} \mathrm{~Pb} /{ }^{207} \mathrm{~Pb}\right.$ and $\left.{ }^{208} \mathrm{~Pb} /{ }^{206} \mathrm{~Pb}\right)$

254 to model the anthropogenic contribution (in \% of total $\mathrm{Pb}$ ) versus time for both sites. Although

255 FRUITS was made for dietary reconstruction, it is a general mixing model suitable for

256 environmental isotopic modeling (e.g. Fernandes et al., 2014). FRUITS manual recommends to

257 not using too many sources vs proxies, no more than +1 (i.e. if you have 2 isotope ratios, you

258 shouldn't be asking FRUITS to attribute to more than 3 sources which is our case). For our

259 modeling, natural endmembers comprised the mean background values specific to each site. The

260 anthropogenic endmember for both sites was calculated from the mean of published Southwest

261 Poland coal, ore, and slag lead isotopic signatures (Tyszka et al., 2012). The dust endmember for

262 both sites was taken from Veron et al. (2014). 


\section{RESULTS}

\subsection{Sediment Characterization}

Troel-Smith core logging results show sediment at Radzyń Chełmiński is composed of 1)

267 highly humified Turfa herbacea and organic lake mud from 0 to $27 \mathrm{~cm}$ with a diffuse boundary;

268 2) organic lake mud with $10 \%$ to $1 \%$ roots from $27 \mathrm{~cm}$ to the bottom of the core. At Rywałd, 269 sediment is composed of 1) Argilla granosa: silt with roots to partially humified Turfa herbacea 270 peat from 0 to $43 \mathrm{~cm}$ with a sharp boundary; 2) silt and clay argilla with 5\% roots from 43 to 68 $271 \mathrm{~cm}$ with a sharp boundary; 3) organic lake mud composed of silty sand to sandy silt from $87 \mathrm{~cm}$ 272 to the bottom of the core (SI_2, SI_3).

274 size for both sites ranged from 0.46 to 3080 microns, ranging in grain size class from fine clay to 275 very fine gravel. The average grainsize at Radzyń Chełmiński was silt (55.56 to 62 microns) from 2760 to about $30 \mathrm{~cm}$, and very fine sand (62 microns to 104 microns) from $30 \mathrm{~cm}$ to the bottom of the

277 278 279

280 281 282 283 284 285 core. Percentages for clay, silt, and sand ranged from 0.67 to $3 \%, 50$ to $69 \%$, and 27 to $49 \%$, respectively. At Rywałd all sediment was very fine sand (62 to 125 microns) apart from $42 \mathrm{~cm}$ with an average particle size 126.25 microns (fine sand) (SI_4). Percentages for clay, silt, and sand ranged from 0.02 to $2 \%, 40$ to $61 \%$, and 23 to $50 \%$, respectively.

\section{$\underline{\text { 3.2 Lead Enrichment Factor and Isotopic Compositions }}$}

Radzyń Chełmiński and Rywałd profiles for $\mathrm{Pb}$ enrichment factor relative to average continental crust (E.F.; McLennan, 2001), and ${ }^{206} \mathrm{~Pb} /{ }^{207} \mathrm{~Pb}$ are provided in Figure 2. Age values are based on the average age modelled by $2 \sigma$ Bayesian modelled uncertainties. Lead is enriched 
by a factor of 14 to 60, and 13 to 159 for Radzyń Chełmiński and Rywałd, respectively. At Rywałd, there is a sharp decrease from $\sim 150$ at the top of the core to 75 around A.D. 1980, then further decrease to a minimum Pb E.F. of 37 around A.D. 1755 147 . Lead enrichment factor at Rywałd then varies between 33 and 70 down to A.D. $1104 \pm 80$, increases to the maximum E.F. of 159 around A.D. 1024 \pm 94 , and steadily decreases to 14 (A.D. $731 \pm 109$ ), where the Pb E.F. becomes relatively stable around $15 \pm 2$ to the bottom of the core (A.D. $572 \pm 8$ ). At Radzyń Chełmiński, Pb E.F. decreases from 81 at the top of the sediment core to 38 at A.D. $1621 \pm 166$, with a minor increase to 58 (A.D. $1587 \pm 148$ ) and continuing decrease to 30 at A.D. $1500 \pm 130$. Enrichment factor remains relatively stable with minor variations between 11 and 38 down to A.D. $979 \pm 102$, before decreasing to the minimum value of 14 at A.D. $894 \pm 85$, maintaining the same Pb E.F. until the bottom of the core (A.D. $803 \pm 99$ ).

For both sites, the ${ }^{206} \mathrm{~Pb} /{ }^{207} \mathrm{~Pb}$ ratio ranges from 1.17 to $1.27 \%$. At Radzyń Chełmiński, three zones can be defined. From the top of the core the ratio increases with age from $1.18 \%$ to $1.27 \%$ at A.D $1227 \pm 112$, then decreases to $1.18 \%$ at A.D. $934 \pm 97$. From this minimum, the ${ }^{206} \mathrm{~Pb} /{ }^{207} \mathrm{~Pb}$ ratio increases to $1.25 \%$ at the bottom of the core (A.D. $803 \pm 99$ ). Five ${ }^{206} \mathrm{~Pb} /{ }^{207} \mathrm{~Pb}$ zones can be identified for Rywałd. From the top of the core to A.D. $1443 \pm 114$, the isotopic ratio increases from $1.17 \%$ o to $1.21 \%$, then remains constant at $1.21 \pm 0.05 \%$ o down to A.D. $1395 \pm 68$. The ${ }^{206} \mathrm{~Pb} /{ }^{207} \mathrm{~Pb}$ ratio continues to increase to $1.25 \%$ at A.D. $1253 \pm 44$, decreases to $1.18 \%$ at A.D. $1083 \pm 82$, remains constant at $1.18 \%$ o to A.D. $768 \pm 106$, and significantly increases to $1.25 \%$ at A.D. $572 \pm 81$. These isotopic profiles are very different from those of previous published data of nearby sites from Northern Poland and Belgium (Fig. 2C; De Vleeschouwer et al., 2009b, Fagel et al., 2014), which show a similar trend to one another over time, with much lower and rather constant ${ }^{206} \mathrm{~Pb} /{ }^{207} \mathrm{~Pb}$ values $(1.14-1.18 \%$ ) than our new dataset. 
From the top of both cores to about A.D. 1700, as Pb E.F. decreases, the ${ }^{206} \mathrm{~Pb} /{ }^{207} \mathrm{~Pb}$ ratio increases. Lead E.F. and isotope ratios have a weak negative correlation, with higher Pb E.F.s coinciding with lower ${ }^{206} \mathrm{~Pb} /{ }^{207} \mathrm{~Pb}$ values.

\section{DISCUSSION}

\subsection{Identification of Lead Sources} $\mathrm{Pb}$ sources by comparing ${ }^{206} \mathrm{~Pb} /{ }^{207} \mathrm{~Pb}$ and ${ }^{208} \mathrm{~Pb} /{ }^{206} \mathrm{~Pb}$ ratios (Fig. 3; Alfonso et al., 2001, Bi et al., 2017, Díaz-Somoano et al., 2009, Harlavan et al., 2010, Monna et al., 2000, Zohar et al., 2014).

Background sample averages from both sites (natural $\mathrm{Pb}$ isotopic ratio endmember: Radzyń Chełmiński: ${ }^{206} \mathrm{~Pb} /{ }^{207} \mathrm{~Pb}=1.33 \pm 0.01 \%$; ${ }^{208} \mathrm{~Pb} /{ }^{206} \mathrm{~Pb}=1.97 \pm 0.004 \%$; Rywałd: ${ }^{206} \mathrm{~Pb} /{ }^{207} \mathrm{~Pb}=$ $1.30 \pm 0.02 \% ;{ }^{208} \mathrm{~Pb} /{ }^{206} \mathrm{~Pb}=1.96 \pm 0.03 \%$ ) and Southwest Poland coal, ore, and slag combined 321 average (anthropogenic endmember: ${ }^{206} \mathrm{~Pb} /{ }^{207} \mathrm{~Pb}=1.17 \pm 0.01 \%$ and ${ }^{208} \mathrm{~Pb} /{ }^{206} \mathrm{~Pb}=2.09 \pm 0.01 \%$; 322 Tyszka et al., 2012) were also included in Figure 3. Lead isotopic ratios for both Radzyń 323 Chełmiński fall along a single trend line between the anthropogenic endmember and an 324 endmember similar to the background averages. Due to the glacial till composition of background 325 sediment, $\mathrm{Pb}$ isotopic ratios for samples are not perfectly linear with background ratios. Overall, 326 the ${ }^{206} \mathrm{~Pb} /{ }^{207} \mathrm{~Pb}$ ratio ranges from 1.18 to $1.28 \%$ for Radzyń Chełmiński, and 1.17 to $1.25 \%$ for 327 Rywałd. The ${ }^{208} \mathrm{~Pb} /{ }^{206} \mathrm{~Pb}$ ratio for Radzyń Chełmiński ranges from 1.96 to 2.08\%, and 1.98 to $3282.10 \%$ for Rywałd. Error bars representing 1 standard deviation for all averages are included 329 (Southern Poland coal, ore and slag ${ }^{206} \mathrm{~Pb} /{ }^{207} \mathrm{~Pb}=1.17 \pm 0.01 ;{ }^{208} \mathrm{~Pb} /{ }^{206} \mathrm{~Pb}=2.09 \pm 0.01$; Radzyń 
Chełmiński background ${ }^{206} \mathrm{~Pb} /{ }^{207} \mathrm{~Pb}=1.33 \pm 0.01 ;{ }^{208} \mathrm{~Pb} /{ }^{206} \mathrm{~Pb}=1.97 \pm 0.004$; Rywałd background $\left.{ }^{206} \mathrm{~Pb} /{ }^{207} \mathrm{~Pb}=1.30 \pm 0.03 ;{ }^{208} \mathrm{~Pb} /{ }^{206} \mathrm{~Pb}=1.96 \pm 0.03\right)$.

Compared to other similarly aged Central European sedimentary records, our new dataset displays significant differences (e.g. Fagel et al., 2014, Zillen et al., 2012, De Vleeschouwer et al., 2009b). Previously published data from the North Poland Bog (Słowińskie Błoto Bog; De Vleeschouwer et al., 2009b) fall along the same trend line. However, the North Poland bog displays an isotopic composition almost entirely from Southwest Poland coal and ore, indicating a much stronger regional anthropogenic signal, with little to no natural $\mathrm{Pb}$ input as indicated in the previous study (Fig. 3; De Vleeschouwer et al., 2009b). In addition, the North Poland Bog indicates an entirely anthropogenic source, with lower ${ }^{206} \mathrm{~Pb} /{ }^{207} \mathrm{~Pb}$ and ${ }^{208} \mathrm{~Pb} /{ }^{206} \mathrm{~Pb}$ than that of the Southwest Poland anthropogenic end members. Such source dissimilarity is expected. Unlike Radzyń Chełmiński and Rywałd, Słowińskie Błoto is a raised (ombrotrophic) peat bog. Signals from peat sediment are expected to record mostly atmospheric inputs (solely rain), versus lake sediment from the current study which include both terrestrial sediment (from runoff) and atmospheric inputs (e.g. Fagel et al., 2014, Thevenon et al., 2011).

\subsection{Changes in Lead Sources Over Time}

\subsubsection{Anthropogenic Sources}

Lead isotopic data processed using FRUITS, a Bayesian mixing model, quantified the importance of anthropogenic $\mathrm{Pb}$ inputs for each depth sampled (Fig. 4). Climatic periods included in bars below both graphs present cold periods as blue bars, and warm periods as red bars. Arrows along the top of Figure 4 indicate the building of a Teutonic Order fort (A.D. 1234; Urban, 1980) 
352 and castle (late $13^{\text {th }}$ century; Urban, 1980) at Radzyń Chełmiński; this activity would not have 353 impacted Rywałd.

Modeled anthropogenic $\mathrm{Pb}$ contribution is described from oldest to most recent inputs (Fig. 4). At Radzyń Chełmiński, the fraction of total lead attributed to anthropogenic inputs in the oldest

356 sediments appears to be influenced by anthropogenic $\mathrm{Pb}$ pollution from A.D. $883 \pm 99$ to A.D. 357 1054 \pm 104 . Contribution of Southwest Poland coal, ore, and slag during that period reaches a maximum of $35 \%$ at A.D. $979 \pm 97$. The anthropogenic fraction of total $\mathrm{Pb}$ remains below $1 \%$ from A.D. $1168 \pm 114$ to with A.D. $1296 \pm 94$, then increases from the beginning of the 14 th century towards a dominantly anthropogenic contribution at the top of the core (up to 65\%).

At Rywałd, the modeled anthropogenic contribution increases from the core bottom to reach a maximum in A.D. $973 \pm 80$ of $65 \%$, and decrease to $1 \%$ at A.D. $1223 \pm 45$. Subsequently, the contribution sharply increases to $49 \%$ in A.D. $1303 \pm 54$ and remains relatively stable with an average value of $38 \pm 8 \%$ to the top of the core, with the exceptions of the two most recent samples 365 (74 and 86\%).

\subsubsection{Mining Activity - Long Range Transport}

Atmospheric anthropogenic $\mathrm{Pb}$ signatures are expected to have been transported from regional mines. Approximately $400 \mathrm{~km}$ to the south of Radzyń Chełmiński and Rywałd, in the

370 Rudawy Janowickie Mountains of Southwest Poland, a series of mines were active periodically 371 over the last millennium (e.g. Kierczak and Pietranik, 2011). Primary ores from Southwest Poland 372 include bituminous and brown coal, $\mathrm{Cu}, \mathrm{Zn}$, and $\mathrm{Pb}$ ores, native $\mathrm{S}$, and rock salt (Rybicka, 1996). 373 Samples from Janowice, Wielkie, Szklary, Legnica, Miedzianka, and Wałbrzych sites in 
374 Southwest Poland were used to represent an anthropogenic contribution (Fig. 4; Tyszka et al.,

375 2012). These mines are the nearest likely source of anthropogenic $\mathrm{Pb}$ in sediments from both

376 Radzyń Chełmiński and Rywałd. Documentation and precise dates are scarce prior to the 1800s,

377 but evidence can be pieced together through the few historical records available and archaeological

378 evidence.

379

First known $\mathrm{Zn}-\mathrm{Pb}$ ore exploitation in Southwest Poland began in the Cracow-Silesia district during the $12^{\text {th }}$ to $13^{\text {th }}$ centuries (Cabala et al., 2013). Mining and smelting of $\mathrm{Cu}$ in the

381 Rudawy Janowickie Mountains has occurred from the $14^{\text {th }}$ century to present (e.g. Bukowski, 382 2011, Kierczak et al., 2013). Miedzianka, in particular was the largest center of mining and 383 smelting $\mathrm{Cu}$, As, and $\mathrm{Ag}$ in Silesia, beginning as early as A.D. 1310 (Kierczak and Pietranik, 384 2011). These mining activities are probably responsible for the change in $\mathrm{Pb}$ isotopic ratios 385 observed at Rywałd just after A.D. 1200 (Fig. 4). Copper slags were deposited in the mountains 386 from the $14^{\text {th }}$ to $16^{\text {th }}$ century (Kierczak et al., 2013). Exploitation peaked in the $16^{\text {th }}$ century, when 387 resources were exhausted, declining until the end of the $17^{\text {th }}$ century (Kierczak and Pietranik, 388 2011). Our data indicates that this historical record of mining activity resulted in lead pollution 389 throughout the region, as shown by the relatively stable anthropogenic contribution in Rywałd for 390 the same time period followed by a small decrease. Ore mining activities became prevalent again 391 from the beginning of the $18^{\text {th }}$ century to the beginning of the $19^{\text {th }}$ century, focusing on Cu-rich 392 ore, as anthropogenic $\mathrm{Pb}$ again increases at Rywałd. Mining and smelting in the Rudawy 393 Janowickie mountains ceased entirely in A.D. 1925 (Kierczak and Pietranik, 2011, Kierczak et al., 394 2013).

Coal exploitation was also prevalent in the Rudawy Janowickie Mountains of Southwest

396 Poland from the $12^{\text {th }}$ century onwards, including two key basins, the Upper Silesian Coal Basin 
(Bukowski, 2011, Rybicka, 1996) and the Lower Silesian Coal Basin (LSCB; Rybicka, 1996). Ore was also mined in these basins. In Bytom and Olkusz, sub districts of the Upper Silesian Coal Basin, $\mathrm{Pb}, \mathrm{Zn}$, and $\mathrm{Cd}$ ores were mined since the $12^{\text {th }}-14^{\text {th }}$ century (depending on source; Ciarkowska et al., 2016, Rybicka, 1996,).

Additionally, from the 1800s onwards, anthropogenic contributions from modern mining, bituminous coal combustion, and leaded gasoline exerted substantial control of the sedimentary $\mathrm{Pb}$ isotopic compositions and concentrations at both sites, as documented in previous studies (e.g. De Vleeschouwer et al., 2009b, Fialkiewicz-Koziel et al., 2018).

To test our hypothesis, a simple mass-balance calculation was applied. At Radzyn by considering only the first $60 \mathrm{~cm}$ with a bulk density of approximately $1000 \mathrm{~kg} / \mathrm{m}^{3}$, where a mean increase in total $\mathrm{Pb}$ of about 5-10 ppm above baseline values can be observed, and by simplifying the time required to accumulate these sediments to 1000 years, we can estimate an average deposition rate of 3-6 mg. $\mathrm{m}^{-2} \mathrm{y}^{-1}$. Considering this range of deposition rate, we cannot exclude influences from other sources either local or distant.

\subsubsection{Land Use within Castle Lake Watershed - Short Range Transport}

Earliest palynological records at Radzyń Chełmiński suggest the region was dominated by woodland with evidence of local small-scale agricultural activities present around A.D. 0-700 (Brown et al., 2015). The Wielbark culture was present in the area from the $2^{\text {nd }}$ to the $5^{\text {th }}$ century A.D., during the Migration period (A.D. 300 to 700 ). The $5^{\text {th }}$ to $9^{\text {th }}$ century is marked by archaeological evidence of tumuli and stone graves in the forest surrounding Radzyń Chełmiński, with remains of a Slavonic settlement adjacent to the forest (Samojlik et al., 2013). There is also 
419 archaeological evidence of depopulation from the $4^{\text {th }}$ century until Slavic settlement from the $7^{\text {th }}$ 420 century (Buko, 2008). A Slavic stronghold was constructed in proximity to Castle Lake around the 421 late $9^{\text {th }}$ century (e.g. Urban, 1980). controlled by a Slavic Stronghold, occupied from the late $9^{\text {th }}$ to $\mathrm{mid} 12^{\text {th }}$ century when it may have

424 been burnt down in an attack (Brown et al., 2015, Chudziak, 1994). Concurrently, there was an 425 intensification in agricultural activity and decrease in woodland, causing increased soil erosion 426 into the surrounding wetland, as presented by palynological evidence (Brown et al., 2015; 427 Chudziak, 1996). Such erosion and increased land-use may have contributed to a decrease in 428 recorded anthropogenic contribution and $\mathrm{Pb}$ concentration at Radzyń Chełmiński. Palynological 429 evidence describes an increasingly open landscape in the pre-Crusading period $\left(11^{\text {th }}\right.$ to $12^{\text {th }}$ 430 century) of both intensifying arable and pastoral activity, with woodland retained on nearby land 431 (Brown et al., 2015). 433 when the Order ceded the territory to Polish control (Pluskowski, 2013; Urban, 1980). The 434 Crusading period began in A.D. 1230, concurrent with the founding of the Teutonic Order castle 435 and town at Radzyń Chełmiński (Brown et al., 2015). During this period agricultural and pastoral 436 land-use was relatively stable surrounding the Castle Lake (Brown et al., 2015). A timber fort was 437 constructed in A.D. 1234, and the castle was later built between A.D. 1310 and 1340 (e.g. Brown 438 et al., 2015). Previously published palynological evidence from Radzyń Chełmiński recorded 439 changes in vegetation and land use during this period, including a decrease in arboreal pollen and 440 increase in cereal pollen (Brown and Pluskowski, 2011; Pluskowski, 2013). The period between 441 A.D. 1350 and 1400 is known as the "Golden Age" of Teutonic Order influence (e.g. Pluskowski, 
442

443

444

445

446

447

448

449

450

451

452

453

454

455

456

457

458

459

460

461

462

463

464
2013). Heathland developed along with agricultural intensification from the late $14^{\text {th }}$ to $15^{\text {th }}$ century, accompanied by a decrease in woodland area (Brown and Pluskowski, 2011). In addition to landscape changes with the arrival of the Teutonic Order, trade routes also developed by efforts to exploit Prussian resources, adding to human impact from the nearby settlements (Harte and Ponting, 1983). As the frontier land between Teutonic Order Prussia and Poland, the Chełmo land (Kulmerland in German), including Radzyń Chełmiński and Rywałd experienced intermittent raids from Prussian tribes, including the Great Prussian Uprising of the 1260s, and subsequent transformation of the landscape (Lukowski and Zawadzki, 2001; Pluskowski, 2013). Such agricultural intensification and castle building may have contributed to altered the regional anthropogenic isotopic signal from the opening of mines within the sediment records, minimizing the expected increase in anthropogenic $\mathrm{Pb}$ contribution that was detected at Rywałd, while at the same time causing an increase in $\mathrm{Pb}$ concentration.

In A.D. 1410, Radzyń Chełmiński Castle was damaged by Polish-Lithuanians (e.g. Pluskowski, 2013). From A.D. 1412 to 1439, the surrounding landscape was subjected to multiple seasons of crop failure, causing many villages in the area to be covered by woodland by A.D. 1444 . The Thirteen Years war occurred shortly after, from A.D. 1453 to 1466, with many conflicts occurring near Radzyń, after which the castle became occupied by Poland (e.g. Pluskowski, 2013), falling into ruin by the $16^{\text {th }}$ century (Brown et al., 2015). Further damage occurred during the Swedish Invasion from A.D. 1626 to 1629 (e.g. Brown et al., 2015). Wooded areas contribute minimal weathered and eroded sediment to the surrounding basin, compared to predominantly open fields (arable and pastoral land). The decrease in local influence from the nearby castle and town, and re-establishment of woodlands, may have allowed for a return to a predominantly regional, atmospheric $\mathrm{Pb}$-derived signal in the sediment record during this period. 


\subsubsection{Regional Climatic Influence}

Differentiating between climatic and historical influences remains challenging. Although

$\mathrm{Pb}$ isotopes are not climate proxies, it is possible climate change or influencing meteorological

469 conditions (e.g. change in dominant wind direction patterns, increase in rainfall, flood events, etc.)

470

471

472

473

474

475

476

477

478

479

480

481

482

483

484

485

486

might indirectly influence $\mathrm{Pb}$ isotopic signatures by promoting the development of human activities (e.g. Büntgen et al., 2016, 2011), mostly during warmer and dryer periods. According to our sediment data (SI_2, SI_3), the Radzyń Chełmiński core is made entirely of lake $\mathrm{mud} / \mathrm{sediment}$; while Rywałd contains peat sediment from 0 to $68 \mathrm{~cm}$, and lake mud/sediment from $68 \mathrm{~cm}$ to the bottom of the core.

Sedimentary records for both cores span five climatic periods: 1) Late Antique Little Ice Age (LALIA, A.D. 536 to 660; e.g. Berglund et al., 2003; Büntgen et al., 2016); 2) the Climatic Optimum in Prussia (COP, A.D. 800 to 1150; e.g. Pluskowski, 2013); 3) the Medieval Warm Period (MWP; A.D. 800 to 1300; e.g. De Vleeschouwer et al., 2009b); 4) the Little Ice Age (LIA; A.D. 1300 to 1850; e.g. De Vleeschouwer et al., 2009b; Hegerl et al., 2017; Lockwood, 2001); and 5) Global Warming (GW; A.D. 1890 to present; e.g. Chiriloaei et al., 2012; Hegerl et al., 2017). Unlike in Western Europe, Prussian communities did not experience a regression after the medieval warm period, and instead thrived (Pluskowski, 2013). We hypothesize that promotion of human activities during favorable climatic conditions (Büntgen et al., 2016) included behaviors that mobilize lead, such as coal burning and ore utilization.

\section{CONCLUSION}


In this study, $\mathrm{Pb}$ concentrations and isotope ratios were used to quantify anthropogenic lead 488 inputs and sources, as well as to identify trends in human activity in Northern Poland over the last 4891,500 years. The use of a rural lake sediment core at Rywałd and a lake core influenced by a nearby 490 town and Teutonic Order castle at Radzyń Chełmiński enabled differentiation between local and 491 regional anthropogenic inputs.

Two primary $\mathrm{Pb}$ sources have been identified: (1) coal, ore, and slag originated from

493 Southwestern Poland mining activities (long range transport); and (2) erosion from the surrounding 494 watershed associated with the development of human activities (short range transport). High 495 anthropogenic $\mathrm{Pb}$ contributions from the 9th to 11th centuries A.D., in the absence of historical 496 evidence for mining activity in Southwestern Poland, point to a previously-unrecognized, 497 substantial anthropogenic $\mathrm{pb}$ source during that time period. Local activities dominated the $\mathrm{Pb}$ 498 isotopic record from the $11^{\text {th }}$ to $13^{\text {th }}$ centuries A.D., during periods of Slavic and subsequent 499 Teutonic Order settlement and castle building, and agricultural intensification. The long range, 500 anthropogenic, mining signal was elevated around the $16^{\text {th }}$ and $18^{\text {th }}$ to $19^{\text {th }}$ centuries A.D., during 501 periods of decreased local human agricultural activity.

Overall, the sediments at Rywałd recorded mostly long range mining inputs originating 503 from Southwest Poland, while Radzyń Chełmiński sediments recorded both sources long range 504 mining signal and local signal from an increase in agricultural and other human activities related 505 to the development of the town and castle. Further studies are required to identify the sources 506 responsible for the anthropogenic signal observed for our sites prior to A.D. 1000. 
The research leading to the results has received funding from the European Union's

510 Seventh Framework Programme (FP7/2007-2013) under grant agreement no. 263735, The

511 Ecology of Crusading. A.C. thanks the U.S. National Science Foundation (Award EAR-1503596)

512 for funding this research. A.C. acknowledges the Donors of the American Chemical Society

513 Petroleum Research Fund (ACS-PRF 54583-DNI2) for supporting this research. We thank two

514 anonymous reviewers for their constructive comments.

515

\section{REFERENCES}

517 Alfonso, S., Grousset, F., Masse, L., \& Tastet, J., 2001. A European lead isotope signal recorded 518 from 6000 to 300 years BP in coastal marshes (SW France). Atmospheric Environment. 35, 519 3595-3605. https://doi.org/10.1016/s1352-2310(00)00566-5

520 Audry, S., Pokrovsky, O.S., Shirikova, L.S., Kirpoten, S.N., Dupre, B., 2011. Organic matter 521 mineralization and trace element post-depositional redistribution in Western Siberia 522 thermokarst lake sediments. Biogeosciences. 8, 3341-3358. https://doi.org/10.5194/bgd-8$523 \quad \underline{8845-2011}$

524 Baron, S., Carignan, J., Ploquin, A., 2006. Dispersion of Heavy Metals (Metalloids) in Soils from 525 800-Year-Old Pollution (Mont-Lozere, France). Environ. Sci. Technol. 40, 5319-5326. 526 https://doi.org/10.1021/es0606430

527 Berglund, B.E., 2003. Human Impact and climate changes - synchronous events and a causal link? Quaternary International. 105, 7-12. https://doi.org/10.1016/s1040-6182(02)00144-1 
529 Bi, X.-Y., Li, Z.-G., Wang, S.-X., Zhang, L., Xu, R., Liu, J.-L., Yang, H.-M., Guo, M.-Z., 2017. Lead

530

531

532

533 534

535

536

537

538

539 Blaauw, M., Christen, J.A., 2011. Flexible Paleoclimate Age-Depth Models Using an Autoregressive

540 Gamma Process. Bayesian Analysis. 6, 3, 457-474. https://doi.org/10.1214/11-BA618

Isotopic Compositions of Selected Coals, $\mathrm{Pb} / \mathrm{Zn}$ Ores and Fuels in China and the Application for Source Tracing. Environmental Science \& Technology. 51, 13502-13508. https://doi.org/10.1021/acs.est.7b04119

Bjőrck S., Wohlfarth, D., 2002. 14C chronostratigraphic techniques in paleolimnology, in: Smol J.P., Birks H.J.B., Last W.M., (eds.) Tracking Environmental Change Using Lake Sediments, vol 1.Kluwer Academic Publishers, Dordrecht, pp. 205-245.

raised bogs: non-existence of a previously reported 'reservoir effect'. Quat. Sci. Rev. 23, 1537-1542.

541 Brown, A., Pluskowski, A., 2011. Detecting the environmental impact of the Baltic Crusades on a

542

543

544

545 Brown, A., Banerjea, R. Wynne, AD, Stivrins, N., Jarzebowski, M., Shillito, L-M., Pluskowski, A., 546

547

548

549 late-medieval (13th-15th century) frontier landscape: palynological analysis from Malbork Castle and hinterland, Northern Poland. Journal of Archaeological Science. 38(8), 19571966. https://doi.org/10.1016/j.jas.2011.04.010 2015. The ecological Impact of conquest and colonization on a Medieval Frontier Landscape: Combined Palynological and Geochemical Analysis of Lake Sediments from Radzyń Chełmiński, Northern Poland. Geoarchaeology: An International Journal. 30, 511-527. https://doi.org/10.1002/gea.21525 
550 Brown, A., 2019. Vegetation changes in Prussia: the palynological data. In A.G. Pluskowski (ed.) 551 Environment, Colonisation, and the Crusader States in Medieval Livonia and Prussia. $552 \quad$ Brepols.

553 Buko, A., 2008. The archaeology of early medieval Poland: Discoveries - hypotheses $554 \quad$ interpretations. Leiden: Brill.

555 Bukowski, P., 2011. Water Hazard Assessment in Active Shafts in Upper Silesian Coal Basin Mines. 556 Mine Water Environ. 30, 302-311. https://doi.org/10.1007/s10230-011-0148-2

557 Büntgen, U., Myglan, V.S., Ljungqvist, F.C., McCormick, M., Cosmo, N.D, Sigl, M., Jungclaus, J., 558 Wagner, S., Krusic, P.J., Esper, J., Kaplan, J.O., de Vaan, M.A.C., Luterbacher, J., Wacker, 559 L., Tegel, W., Kirdyanov, A.V., 2016. Cooling and societal change during the Late Antique 560 Little Ice Age from 536 to around 660 AD. Nature Geoscience. 9, 231-236. 561 https://doi.org/10.1038/ngeo2652

562 Büntgen, U., Tegel, W., Nicolussi, K., McCormick, M., Frank, D., Trouet, V., Kaplan, J.O., Herzig, 563 F., Heussner, K.-U., Wanner, H., Luterbacher, J., Esper, J., 2011. 2500 Years of European 564 Climate Variability and Human Susceptibility. Science, 331, 578-582. $565 \quad$ https://doi.org/10.1126/science.1197175

566 Butz, C., Grosjean, M., Goslar, T., et a., 2017. Hyperspectral imaging of sedimentary bacterial 567 pigments: a 1700-year history of meromixis from varved Lake Jaczno, northeast Poland. J.

$568 \quad$ Palaeolimnol. 58, 57-72. 
569 Cabala, J. Smieja-Krol, B., Jablonska, M., Chrost, L., 2013. Mineral components in a peat deposit: $570 \quad$ looking for signs of early mining and smelting activities in Silesia-Cracow region (Southern 571 Poland). Environ. Earth Sci. 69, 2559-2568. https://doi.org/10.1007/s12665-012-2080-6

572 Cheng, H., Hu, Y., 2010. Lead (Pb) isotopic fingerprinting and its applications in lead pollution 573 studies in China: A review. Environmental Pollution. 158,5, 1134-1146. $574 \quad$ https://doi.org/10.1016/j.envpol.2009.12.028

575 Chester, R., Stoner, J.H., 1973. Pb in particulates from the lower atmosphere of the eastern Atlantic. $576 \quad$ Nature. 24, 27-28. https://doi.org/10.1038/245027b0

577 Chiriloaei, F., Rădoane, M., Perşoiu, I., Popa, I., 2012. Late Holocene history of Moldova River 578 Valley, Romania. Catena. 93, 64-77. https://doi.org/10.1016/i.catena.2012.01.008

579 Chudziak, W., 1996. Zasiedlenie strefy chełmin' sko-dobrzyn' skiej we wczesnym s'redniowieczu $580 \quad$ (VII-XI wiek). Torun': UMK.

581 Ciarkowska, K., Gargiulo, L., Mele, G., 2016. Natural restoration of soils on mine heaps with similar 582 technogenic parent material: A case study of long-term soil evolution in Silesian-Krakow 583 Upland Poland. Geoderma. 261, 141-150. https://doi.org/10.1016/j.geoderma.2015.07.018

584 Cook, J.M., Gardner, M.J., Griffiths, A.H., Jessop, M.A., Ravenscroft, J.E. and Yates, R. (1997) The 585 comparability of sediment digestion techniques for the determination of metals in sediments. $586 \quad$ Marine Pollution Bulletin, 34(8), 637-644.

587 De Vleeschouwer, F., Piotrowska, N., Sikorski, J., Pawlyta, J., Cheburkin, a., Le Roux, G., 588 Lamentowicz, M., Fagel, M., Mauquoy, D., 2009a. Multiproxy evidence of 'Little Ice Age’ 
palaeoenvironmental changes in a peat bog from northern Poland. The Holocene. 19, 4, 625-

591 De Vleeschouwer, F., Fagel, N., Cheburkin, A., Pazdur, A., Sikorski, J., Mattielli, N., Renson, V., 592 Fialkiewicz, B., Piotrowska, N., Le Roux, G., 2009b. Anthropogenic impacts in North Poland 593 over the last 1300 years - A record of $\mathrm{Pb}, \mathrm{Zn}, \mathrm{Cu}, \mathrm{Ni}$ and $\mathrm{S}$ in an ombrotrophic peat bog. 594 Science of the Total Environment. 407(21), 5674-5684. $595 \quad$ https://doi.org/10.1016/j.scitotenv.2009.07.020

596 Díaz-Somoano, M., Kylander, M.E., López-Antón, M.A., Suárez-Ruiz, M.R., Martínez-Tarazona, 597 M., Ferrat, Kober, B., Weiss, D.J., 2009. Stable Lead Isotope Compositions In Selected Coals 598 From Around The World And Implications For Present Day Aerosol Source Tracing. $599 \quad$ Environ. Sci. Technol. 43, 1078-1085.

600 Doe, B. R., 1970. Lead isotopes. Springer Verlag, Berlin, Heidelberg, New York. $601 \quad$ https://doi.org/10.1007/978-3-642-87280-8

602 Fagel, N., Allan, M., Le Roux, G., Mattielli, N. Piotrowska, N., Sikorski, J., 2014. Deciphering 603 human-climate interactions in an ombrotrophic peat record: $\mathrm{REE}, \mathrm{Nd}$ and $\mathrm{Pb}$ isotope 604 signatures of dust supplies over the last 2500years (Misten bog, Belgium). Geochimica et 605 Cosmochimica Acta. 135, 288-306. https://doi.org/10.1016/j.gca.2014.03.014

606 Fernandes, R., Millard, A. R., Brabec, M., Nadeau, M.-J., \& Grootes, P., 2014. Food Reconstruction 607 Using Isotopic Transferred Signals (FRUITS): A Bayesian Model for Diet 608 Reconstruction. PLoS ONE. 9,2. https://doi.org/10.1371/journal.pone.0087436 
609 Fiałkiewicz-Kozieł, B., De Vleeschouwer, F., Mattielli, N., Fagel, N., Palowski, B., Pazdur, A., 610 Smieja-Król, B., 2018. Record of Anthropocene pollution sources of lead in disturbed

611 peatlands from Southern Poland. Atmospheric Environment. 179, 61-68. $612 \quad \underline{\text { https://doi.org/10.1016/j.atmosenv.2018.02.002 }}$

613 Flegal, A.R., Smith, D.R., 1995. Measurements of environmental lead contamination and human 614 exposure. Reviews of Environmental Contamination and Toxicology. 143, 1-45. $615 \quad$ https://doi.org/10.1007/978-1-4612-2542-3_1

616 Gallon, C., Tessier, A., Gobeil, C., Afaro-De La Torre, M. C., 2004. Modeling diagenesis of lead in 617 sediments of a Canadian Shield Lake. Geochimica et Cosmochimica Acta. 68, 17, 3531-3545. $618 \quad$ https://doi.org/10.1016/j.gca.2004.02.013

619 Grousset, F.E., Quetel, C.R., Thomas, B., Buatmenard, P., Donard, O.F.X., Bucher, A., 1994. 620 Transient $\mathrm{Pb}$ Isotopic Signatures in the Western-European Atmosphere. Environ. Sci. 621 Technol. 28, 9, 1605-1608. https://doi.org/10.1021/es00058a011

622 Harlavan, Y., Erel, Y., Blum, J. D., 1998. Systematic Changes in Lead Isotopic Composition with 623 Soil Age in Glacial Granitic Terrains. Geochimica et Cosmochimica Acta. 62,1, 33-46. $624 \quad$ https://doi.org/10.1016/s0016-7037(97)00328-1

625 Harlavan, Y., Almogi-Labin, A., Herut, B., 2010. Tracing Natural and Anthropogenic Pb in 626 Sediments along the Mediterranean Coast of Israel using Pb Isotopes. Environ. Sci. Technol. 627 44, 6576-6582. https://doi.org/10.1021/es9039055 
628 Harte, N.B. \& Ponting, K.G. (Eds), 1983. Cloth and Clothing in Medieval Europe: Essays in Memory 629 of Professor E.M. Carus-Wilson. Heinemann Educational Books Ltd., London.

630 Hegerl, G. C., Brönnimann, S., Schurer, A., Cowan, T., 2017. The early 20th century warming: 631 Anomalies, causes, and consequences. WIREs Clim. Change. 9, e522. 632 https://doi.org/10.1002/wcc.522.

633 Hosono, T., Alvarez, K., Kuwae, M., 2016. Lead isotope ratios in six lake sediment cores from Japan 634 Archipelago: Historical record of trans-boundary pollution sources. Science of the Total 635 Environment. 559, 24-37. https://doi.org/10.1016/j.scitotenv.2016.03.138

636 Huerta-Diaz, M. A., Tessier, A., Carignan, R., 1998. Geochemistry of trace metals associated with 637 reduced sulfur in freshwater sediments, Applied Geochemistry. 13, 213-233. $638 \quad$ https://doi.org/10.1016/s0883-2927(97)00060-7

639 Kierczak, J., Pietranik, A., 2011. Mineralogy and composition of historical Cu Slags from the 640 Rudawy Janowickie Mountains, Southwestern Poland. The Canadian Mineralogist. 49, 1281641 1296. https://doi.org/10.3749/canmin.49.5.1281

642 Kierczak, J., Potysz, A., Pietranik, A., Tyszka, R., Modelska, M., Néel, C., Ettler, V., Mihaljevič, 643 M., 2013. Environmental impact of the historical $\mathrm{Cu}$ smelting in the Rudawy Janowickie 644 Mountains (south-western Poland). J. Geochemical Exploration. 124, 183-194. 645 https://doi.org/10.1016/j.gexplo.2012.09.008 
646 Komárek, M., Ettler, V., Chrastný, V., Mihaljevič, M., 2008. Lead isotopes in environmental 647 sciences: A review. Environment International. 34, 4, 562-577. $648 \quad$ https://doi.org/10.1016/j.envint.2007.10.005

649 Kylander, M., Weiss, D., Martinezcortizas, A., Spiro, B., Garciasanchez, R., Coles, B., 2005. 650 Refining the pre-industrial atmospheric $\mathrm{Pb}$ isotope evolution curve in Europe using an 8000 651 year old peat core from NW Spain. Earth and Planetary Science Letters. 240, 2, 467-485. $652 \quad$ https://doi.org/10.1016/j.eps1.2005.09.024

653 Lanphear, B.P., Hornung, R., Khoury, J., Yolton, K., Baghurst, P., Bellinger, D.C., Canfield, R.L., 654 Dietrich, K.N., Bornschein, R., Greene, T., Rothenberg, S.J., Needleman, H.L., Schnaas, L., 655 Wasserman, G., Graziano, J., Roberts, R., 2005. Low-Level Environment Lead Exposure and 656 Children's Intellectual Function: An International Pooled Analysis. Environmental Health $657 \quad$ Perspectives, 113, 7, 894-899.

658 Lockwood, J.G., 2001. Abrupt and sudden climatic transitions and fluctuations: A Review. Int. J. 659 Climatol. 21, 9, 1153-1179. https://doi.org/10.1002/joc.630.abs

660 Lukowski, J. \& Zawadzki, H., 2001. A Concise History of Poland. Cambridge University Press, $661 \quad$ Cambridge. https://doi.org/10.1017/cbo9780511813856

662 Marks, L., 2012. Timing of the Late Vistulian (Weichselian) glacial phases in Poland. Quaternary 663 Science Reviews. 44, 81-88. https://doi.org/10.1016/j.quascirev.2010.08.008

664 Martínez Cortizas, A., García-Rodeja, E., Pontevedra Pombal, X., Nóvoa Muñoz, J.C., Weiss, D., 665 Cheburkin, A., 2002. Atmospheric Pb deposition in Spain during the Last 4600 years recorded 

Environ. 292, 33-44.

668 Martínez Cortizas, A., López-Merino, L., Bindler, R., Mighall, T., Kylander, M.E., 2016. Early 669 atmospheric metal pollution provides evidence for Chalcolithic/Bronze Age mining and 670 metallurgy in Southwestern Europe. Sci. Total. Environ. 545-546, 398-406. 671 http://dx.doi.org/10.1010/j/scitotenv.2015.12.078

672 McIntyre, A.M., Gueguen, C., 2013. Binding interactions of algal-derived dissolved organic matter 673 with metal ions. Chemosphere.

90 620-626. https://doi.org/10.1016/j.chemosphere.2012.08.057

675 McLennan, S.M., 2001. Relationships between the trace element composition of sedimentary rocks 676 and upper continental crust. Geochemistry, Geophysics, Geosystems. 2, 4, 2000GC000109.

677 https://doi.org/10.1029/2000gc000109

678 Mil-Homens, M., Caetano, M., Costa, A. M., Lebreiro, S., Richter, T., de Stigter, H., Johnson, M., 679 Branco, V., Cesario, R., Mouro, F., Mateus, M., Boer, W., Melo, Z., 2013. Temporal 680 evolution of lead isotope ratios in sediments of the Central Portuguese Margin: A fingerprint 681 of human activities. Marine Pollution Bulletin. 74, 1, 274-284. 682 https://doi.org/10.1016/j.marpolbul.2013.06.044

683 Mil-Homens, M., Vale, C., Brito, P., Naughton, F., Drago, T., Raimundo, J., Anes, B., Schmidt, S., 684 Caetano, M., 2017. Insights of $\mathrm{Pb}$ isotopic signature into the historical evolution and sources 685 of $\mathrm{Pb}$ contamination in a sediment core of the southwestern Iberian Atlantic shelf. Sci Total $686 \quad$ Environ. 586, 473-484. 
687 Monna, F., Hamer, K., Lévêque, J., Sauer, M., 2000. Pb isotopes as a reliable marker of early mining 688 and smelting in the Northern Harz province (Lower Saxony, Germany). Journal of 689 Geochemical Exploration. 68, 201-210. https://doi.org/10.1016/s0375-6742(00)00005-4

690 Nilsson, M., Klarqvist, M., Bohlin, E., et al., 2001. Variation in 14C age of macrofossils and different 691 fractions of minute peat samples dated by AMS. The Holocene 11, 579-586.

692 Novák, M., Emmanuel, S., Vile, M., Erel, Y., Véron, A., Pačes, T., Wieder, R.K., Vanecek, M., 693 Stepanova, M., Brizova, E., Hovorka, J., 2003. Origin of lead in eight European peat bogs 694 determined from isotope ratios, strengths, and operation times of regional pollution sources. 695 Environ. Sci.Technol. 37, 437-45. https://doi.org/10.1021/es0200387

696 Noryśkiewicz, A.M., 2004. Przemiany w szacie ro'slinnejokolic Us'cia w okresie ostatnich dwo' ch 697 tysie, cy lat. In W. Chudziak (Ed.), Wczesnos'redniowieczny zespo' ł osadniczy Kałdusie. 698 Studia przyrodniczo archeologiczne. 151-163.

699 Noryśkiewicz, A.M., 2005. Preliminary results of study on vegetation history in the Linje mire region 700 using pollen analysis. Monographiae Botanicae. 94, 118-133.

701 Pluskowski, A., 2013. The Archaeology of the Prussian Crusade: Holy War and colonization. 702 Routledge, Abington, UK. https://doi.org/10.4324/9780203079867

703 Reimann, C., Flem, B., Fabian, K., Birke, M., Ladenberger, A., Négrel, P., Demetriades, A., 704 Hoogewerff, J., The Gemas Project Team, 2012. Lead and lead isotopes in agricultural soils 705 of Europe - The continental perspective. Applied Geochemistry 27, 3, 532-542. https://doi.org/10.1016/j.apgeochem.2011.12.012 
707 Russell, R.D., Farquhar, R.M., 1960. Lead Isotopes in Geology. Interscience Publishers, New York.

708 Rybicka, E.H., 1996. Impact of mining and metallurgical industries on the environment in Poland.

709 Applied Geochemistry. 11, 3-9. https://doi.org/10.1016/0883-2927(95)00083-6

710 Samojlik, T.; Rotherham, I. D.; Jedrzejewska, B., 2013. Quantifying Historic Human Impacts on

711 Forest Environments: A Case Study in Bialowieza Forest, Poland. Environmental History.

$712 \quad$ 18, 3, 576-602. https://doi.org/10.1093/envhis/emt039

713 Schultz, M.F., Benjamin, M.M., Ferguson, J.F., 1987. Adsorption and desorption of metals on 714 ferrihydrite: reversibility of the reaction and sorption properties of the regenerated solid.

715 Environ. Sci. Technol. 21, 863-869. https://doi.org/10.1021/es00163a003

716 Shotyk, W., 1998. History of Atmospheric Lead Deposition since 12,370 14C yr. BP from a Peat

717 Bog, Jura Mountains, Switzerland. Science. 281, 5383, 1635-1640.

$718 \quad$ https://doi.org/10.1126/science.281.5383.1635

719 Szal, M., Kupryjanowicz, M. Wyczolkowski, M., Tylmann, W., 2014. The Iron Age in the Mrągowo 720 Lake District, Masuria, NE Poland : The Salet settlement microregion as an example of long721 lasting human impact on vegetation. Vegetation History and Archaeobotany. 23, 419-437.

722 Tessier, A., Fortin, D., Belzile, N., Dévitré, R.R., Leppard, G.G., 1996. Metal sorption to diagenetic 723 iron and manganese oxyhydroxides and associated organic matter: Narrowing the gap 724 between field and laboratory measurements. Geochimica et Cosmochimica Acta. 60, 3, 387725 404. https://doi.org/10.1016/0016-7037(95)00413-0 
726 Thevenon, F., Graham, N.D., Chiaradia, M., Arpagaus, P., Wildi, W., Pote, J., 2011. Local to regional 727 scale industrial heavy metal pollution recorded in sediments of large freshwater lakes in

728

729 central Europe (lakes Geneva and Lucerne) over the last centuries. Sci. Tot. Environ. 412413, 239-247. https://doi.org/10.1016/j.scitotenv.2011.09.025

730 Tranvik, L.J., Downing, J.A.., Carter, J.B., et al., 2009. Lakes and reservoirs as regulators of carbon 731 cycling and climate. Limnol. Oceanog. 54, 2298-2314.

732 Tyszka, R., Pietranik, a., Kierczak, J., Ettler, V., Mihaljevič, M., Weber, J., 2012. Anthropogenic and 733 lithogenic sources of lead in Lower Silesia (Southwest Poland): An isotope study of soils, 734 basement rocks and anthropogenic materials. Applied Geochemistry. 27, 6, 1089-1100. 735 https://doi.org/10.1016/j.apgeochem.2012.02.034

736 Urban, W., 1980. The Prussian Crusade. University Press of America, Inc. London, England.

737 Verner, J.F., Ramsey, M.H., Helios-Rybicka, E., Jedrzejczyk, B., 1996. Heavy metal contamination 738 of soils around a Pb-Zn smelter in Bukowno, Poland. Applied Geochemistry. 11, 11-16. 739 https://doi.org/10.1016/0883-2927(95)00093-3.

740 Véron, A., Novak, M., Brizova, E., Stepanova, M., 2014. Environmental imprints of climate changes 741 and anthropogenic activities in the Ore Mountains of Bohemia (Central Europe) since 13 cal.

742 Kyr. BP. The Holocene. 24, 8, 919-931. https://doi.org/10.1177/0959683614534746

743 Wentworth, C.K., 1922. A scale of grade and class terms for clastic sediments. The Journal of 744 Geology. 30, 5, 377-392. https://jstor.org/stable/30063207 
745 Zaborska, A., 2014. Anthropogenic lead concentrations and sources in Baltic Sea sediments based 746 on lead isotopic composition. Marine Pollution Bulletin. 85, 1, 99-113. $747 \quad$ https://doi.org/10.1016/j.marpolbul.2014.06.013

748 Zamoyski, A., 1987. The Polish Way: A thousand year history of the poles and their culture. John 749 Murray Ltd, Great Britain.

750 Zhou, A., Yuxin, H., Shang, X., et al., 2015. Changes in the radiocarbon reservoir age in Lake 751 Xingyun, southwestern China during the Holocene. PLoS One 10, 1-21.

752 Zillen, L., Lenz, C., Jilbert, T., 2012. Stable lead (Pb) isotopes and concentrations - A useful 753 independent dating tool for Baltic Sea sediments. Quaternary Geology. 8, 41-45. $754 \quad$ https://doi.org/10.1016/j.quageo.2011.11.001

755 Zohar, I., Bookman, R., Levin, N., de Stigter., H., Teutsch, N., 2014. Contamination History of Lead 756 and Other Trace Metals Reconstructed from an Urban Winter Pond in the Eastern 757 Mediterranean Coast (Israel). Environ. Sci. Technol. 48, 13592-13600. https://doi.org/10.1021/es500530x 


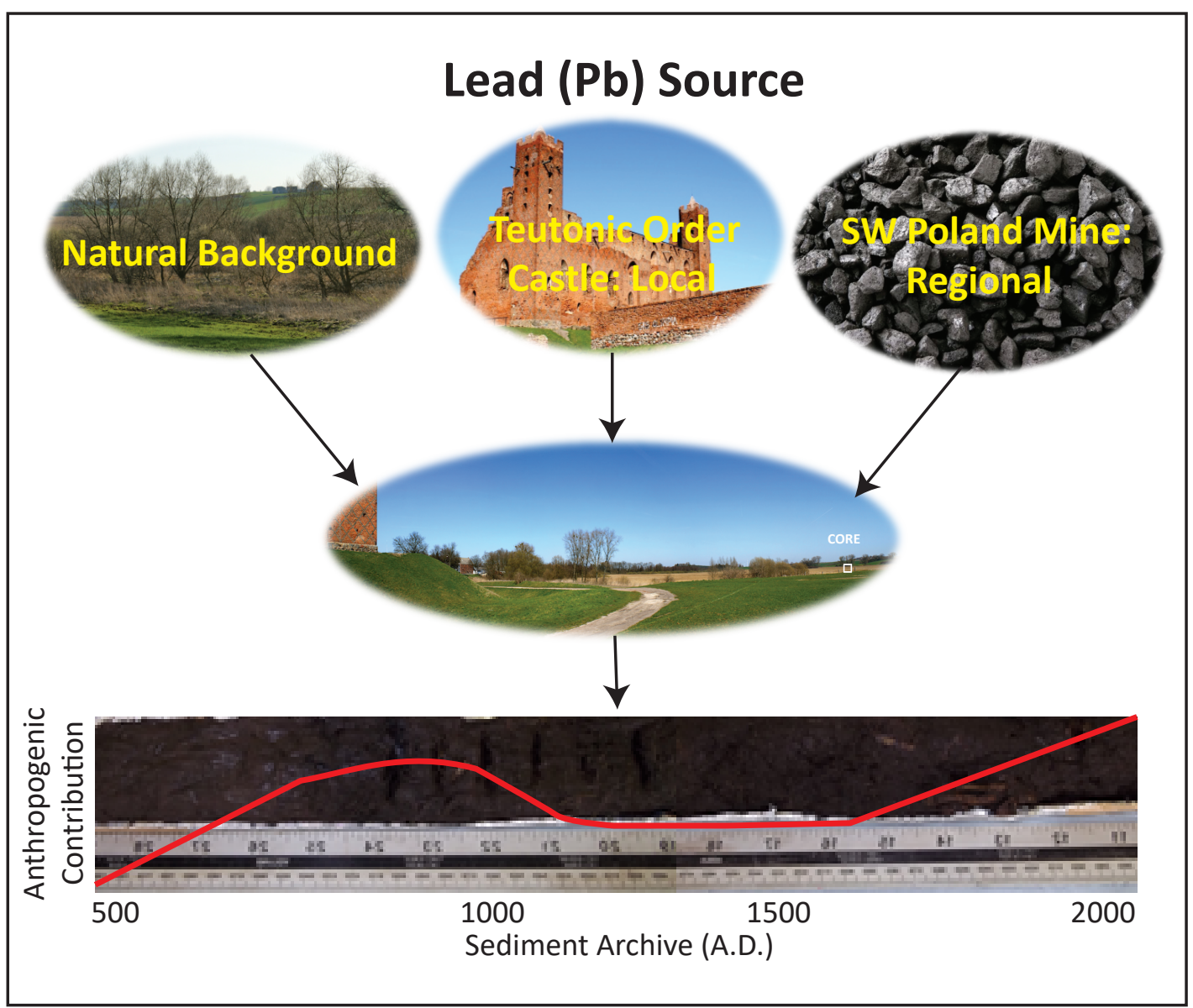




\section{Highlights}

- 1,500 years of paleo-reconstruction using lead isotopes

- Mining contributed significantly to the lead inventory as early at the $13^{\text {th }}$ century via long range transport

- Warmer climate in between 800 and 1,000 A.D. may have favored anthropogenic activities 
3 Heidi B. Babos ${ }^{\mathrm{a}, \mathrm{b}}$, Stuart Black ${ }^{\mathrm{b}}$, Aleks Pluskowski ${ }^{\mathrm{b}}$, Alex Brown ${ }^{\mathrm{b}}$, Megan Rohrssen ${ }^{\mathrm{a}}$, Anthony

$4 \quad$ Chappaz $^{\mathrm{a}}$

5 a Department of Earth and Atmospheric Science, Central Michigan University, Mt. Pleasant, MI,

6 USA

$7 \quad \mathrm{~b}$ Department of Archaeology, School of Archaeology, Geography and Environmental Sciences,

8 University of Reading, Whiteknights, Reading, Berkshire, UK

9 Corresponding author: anthony.c@cmich.edu

11 ABSTRACT

Efforts to study how human activities have influenced the environment since the end of the

13 Roman period to present day are lacking for North Central Europe. Here, we present new lead $(\mathrm{Pb})$

14 isotope data determined from two sediment cores collected from ancient lakes spanning the last

15 1,500 years, located in the Kuyavian-Pomeranian Voivodeship, Poland. Study sites at Radzyń

16 Chełmiński and Rywałd were used to differentiate Pb sources. Radzyń Chełmiński is located in

17 the vicinity of a late Medieval Teutonic Order castle and town, while Rywałd is situated within a

18 relatively pristine area until the $19^{\text {th }}$ century when it became used for agricultural purpose. Core

19 samples were analyzed for $\mathrm{Pb}$ concentration and isotopes $\left({ }^{206} \mathrm{~Pb},{ }^{207} \mathrm{~Pb},{ }^{208} \mathrm{~Pb}\right)$. Bayesian modelling

20 was used to isolate the anthropogenic signal at each site over time. 
For both sites, $\mathrm{Pb}$ enrichment factors relative to titanium (Ti) and upper continental crust

22 values range from 13 to 159. Lead isotopic ratios range from background, pre-anthropogenic local

23 values $\left({ }^{206} \mathrm{~Pb} /{ }^{207} \mathrm{~Pb}=1.31 \pm 0.03 \%\right.$, ${ }^{208} \mathrm{~Pb} /{ }^{206} \mathrm{~Pb}=1.97 \pm 0.04 \%$ ) to anthropogenic values (SW

24 Poland coal, ore, slag ${ }^{206} \mathrm{~Pb} /{ }^{207} \mathrm{~Pb}=1.17 \pm 0.01 \%$, ${ }^{208} \mathrm{~Pb} /{ }^{206} \mathrm{~Pb}=2.09 \pm 0.01 \%$ ). Modeled

25 anthropogenic contribution varies greatly over time, ranging from 14 to 100\%. At Radzyń

26 Chełmiński, modeled anthropogenic $\mathrm{Pb}$ contribution and measured $\mathrm{Pb}$ concentration follow

27 similar trends. However, at Rywałd, from around A.D.1000 to A.D. 1400 these profiles diverge

28 significantly. Our new insights highlight different sources of $\mathrm{Pb}$ from the $12^{\text {th }}$ century to present

29 day: (1) short range agricultural activities from the town, and (2) long range mining activities.

30 Additionally, prior to the $12^{\text {th }}$ century, our data suggest continental anthropogenic activity possibly

31 favored by a warmer climate.

32

33 KEYWORDS

34 Lead - Isotopes - Sediments - Anthropogenic - Sources - Medieval

\section{INTRODUCTION}

Lead $(\mathrm{Pb})$ is a toxic, non-essential, trace element particularly useful for tracking anthropogenic input in environmental archives (e.g. Lanphear et al., 2005). Using Pb isotopes, we

39 can differentiate between anthropogenic (industrial and mining activities, coal and fuel burning;

40 e.g. Cheng and $\mathrm{Hu}, 2010$ ) and natural sources (i.e. natural weathering processes) that release $\mathrm{Pb}$

41 into the environment (Grousset et al., 1994; Thevenon et al., 2011; Zohar et al., 2014); and as a 
42 result, hypothesize on the timing and locations of past human activities (Fagel et al., 2014; Hosono 43 et al., 2016; Zohar et al., 2014).

Three radioisotopes $\left({ }^{206} \mathrm{~Pb},{ }^{207} \mathrm{~Pb},{ }^{208} \mathrm{~Pb}\right)$ are commonly measured for this type of study (Alfonso et al., 2001; Komarek et al., 2008; Reimann et al., 2012). Due to the durations of their half-lives, these isotopes are considered meta-stable in geologically recent sediment (e.g. Russell and Farquhar, 1960). There are no known environmental or industrial processes that fractionate $\mathrm{Pb}$ isotopes, and thus the isotopic composition of $\mathrm{Pb}$ is affected by $\mathrm{Pb}$ source and geologic location 49 (Cheng and Hu, 2010; Doe, 1970; Flegal and Smith, 1995). Additionally, Pb is relatively stable within the sediment column and not readily susceptible to remobilization by early diagenetic 51 processes or biological activities (Audry et al., 2011; Gallon et al., 2004; Harlavan, 1998; HuertaDiaz, 1998; McIntyre and Gueguen, 2013; Schultz et al., 1987; Tessier et al., 1996; ). By analyzing ratios of these three isotopes: ${ }^{206} \mathrm{~Pb} /{ }^{207} \mathrm{~Pb}$ and ${ }^{208} \mathrm{~Pb} /{ }^{206} \mathrm{~Pb}$, it is possible to assess how source 54 contributions of $\mathrm{Pb}$ have changed over time for a given location (Baron et al., 2006; Harlavan et 55 al., 2010; Zohar et al., 2014).

Within the environment, $\mathrm{Pb}$ isotope ratios may be influenced by local, regional, or global

57 sources (e.g. Choi et al., 2007, Martinez Cortizas et al., 2002, 2016, Mil-Homens et al., 2013, 58 2017). For example, In the Iberian Peninsula a number of studies have used $\mathrm{Pb}$ isotope ratios to 59 document evidence of regional metallurgy and mining from the Chalcolithic ( $\sim 3000 \mathrm{BC})$ to 60 modern period (last 200 years; Martinez Cortizas et al., 2002, 2016, Mil-Homens et al., 2013). In marine sediment within the Portuguese Margin, $\mathrm{Pb}$ isotope ratios were also able to record Roman 62 and modern mining activities from the adjacent Iberian region (Mil-Homens et al., 2017, (Include examples from above refs.) Global signatures from atmospheric transport and deposition of $\mathrm{Pb}$, 64 such as Saharan dust storms, and leaded gasoline emissions in modern times, has also been 
65 documented (e.g. Bi et al., 2017, Mil-Homens et al., 2017, Shotyk et al., 1998). For this study, regional sources are defined as mining of coal ore, smelting, and leaded gasoline exhaust.

67 Historical mining activities 300 to $500 \mathrm{~km}$ to the southwest of the study site may have introduced

$68 \mathrm{~Pb}$ to the atmosphere, allowing for transport downwind to the study site. This $\mathrm{Pb}$ transported over

69 long range is deposited, via association with sinking particles, in lake and peat sediments (e.g.

70 Novak et al., 2003). Local sources, on the scale of kilometers or less, can also contribute to $\mathrm{Pb}$

71 enrichments and/or changes in the $\mathrm{Pb}$ isotope ratios in sediments. They include enhanced

72 weathering and erosion of the surrounding landscape due to agricultural activities, building

73 development, metalwork, and domestic coal burning.

75 climatic signal in comparison to the rest of Europe, which is sensitive to both oceanic and 76 continental influences (e.g. Zamoyski, 1987). Specifically, the Medieval Warm Period (MWP)

77 ended in Poland earlier than the rest of Europe (Medieval Warm Period: MWP; A.D. 800 to 1300;

78 e.g. De Vleeschouwer et al., 2009a). The portion of the MWP that influenced Poland is known as 79 the Climatic Optimum in Poland (COP, A.D. 800 to 1150; e.g. Pluskowski, 2013). These climatic 80 patterns may have played two non-mutually exclusive impacts on anthropogenic $\mathrm{Pb}$ contributions:

81 directly by impacting efficiency of atmospheric $\mathrm{Pb}$ long range transport from mining regions, and 82 indirectly through changes in human activity at the vicinity of our study sites associated with these 83 climatic changes. Historical $\mathrm{Pb}$ contamination associated with mining activities in Poland has been 85 documented. The Rudawy Janowickie Mountains of Silesia, in Southwestern Poland were heavily 86 mined for coal, copper $(\mathrm{Cu})$, iron $(\mathrm{Fe})$, silver $(\mathrm{Ag})$, and zinc-lead (Zn-Pb) ores (e.g. Cabala et al., 87 2013; Kierczak et al., 2013; Rybicka, 1996). There is historical documentation of ore mining since 
88 the $12^{\text {th }}$ century, but there may have been mining activity as early as the $5^{\text {th }}$ century A.D.

89 (Ciarkowska et al., 2016; Kierczak et al., 2013; Kylander et al., 2005; Tyszka et al., 2012). Mining

90 activities were recorded as $\mathrm{Pb}$ isotopic ratios and other trace element concentrations in Baltic Sea

91 sediment from the $12^{\text {th }}$ to $17^{\text {th }}$ century A.D. (Zaborska, 2014), and in a bog located in Northern

92 Poland (De Vleeschouwer et al, 2009a, b) from the $9^{\text {th }}$ to $18^{\text {th }}$ century A.D.

Previous studies throughout Europe measured $\mathrm{Pb}$ isotopes in lake and bog sediment to

94

95

96

97

98

99

100

101

102

103

104

105

106

107

108

109

110

estimate the importance and origin of anthropogenic Pb (e.g. Martínez Cortizas et al., 2002).

Sedimentary records from lake and wetland systems act as environmental archives for local and regional anthropogenic activity over time. Ideal study sites for differentiating between local and regional, anthropogenic and non-anthropogenic $\mathrm{Pb}$ sources comprise at least two nearby locations: one rural (relatively pristine) and a second that was influenced by documented human activities. Previous results obtained from sedimentary cores using Pb isotopes from A.D. 500 (post Roman period) to around A.D. 1800 (pre-Industrial Revolution) focus on Western and Central Europe. The few previous studies based to the east of Germany analyzed sediment samples from mountainous regions (Monna et al., 2000; Shotyk, 1998; Véron et al., 2014) and the Baltic Sea (Zillen et al, 2012). Only one study in Northern Poland aimed to track solely regional signals of coal and mining from Southwest Poland (De Vleeschouwer et al., 2009b).

No known high temporal resolution data has been previously published for $\mathrm{Pb}$ isotopes in the Kulmerland region. The main objective of this research was to quantify anthropogenic $\mathrm{Pb}$ pollution over the last 1,500 years at Radzyń Chełmiński, using primarily $\mathrm{Pb}$ isotopic signatures. By comparing similar cores from two nearby sites (one in a rural area and a second in the vicinity of a town), we investigated short range (activity from a surrounding town) versus long range (mining signal from Southwestern Poland) transport pollution, as well as potential indirect climatic 
111 impacts on human development. Our combination of historical context with detailed geochemical

112 data provide new insights about the extent of local and regional pollution dispersal.

\section{2. METHODOLOGY}

$115 \quad \underline{2.1}$ Study Sites

116 Two distinct ancient lake systems within the Chełmo Land, Kuyavian-Pomeranian

117 Voivodeship, Poland were sampled for this study: Radzyń Chełmiński and Rywałd (Figure 1). The

118 Kuyavian-Pomeranian Voivodeship lies along the border of historic Prussia and Poland. It came 119 under Polish control from the mid-10th century and was at the frontier between Polish and Prussian 120 territories. There were increasing raids by Prussians into the 12 th and early 13 th century in 121 response to attempts by Poland to conquer Prussian territories, and eventually Konrad I Duke of 122 Masovia invited in the Teutonic Order to help defend his territories in the early 1230s - with the 123 first timber fortification built at Radzyn in 1234. Historical texts and archaeological studies 124 indicate human settlement from the end of the Roman period (around 300 A.D.) to present (e.g. 125 Pluskowski, 2013). The wetlands, including the Castle Lake, are now largely infilled and covered 126 in sedges, with surface water present to ca. 10-20 cm within the interior of the lake, mostly during 127 the wet winter/spring months.

129 Order castle built between 1310 and 1340 A.D., and a town of approximately 2,000 inhabitants, 130 settled in concurrence with the settlement of the Teutonic Order (early 13th century; Brown et al., 131 2015). The castle remained an important commander center into the 15th century, but was 
132 dissolved in 1454 during the Thirteen Years War (1454-1466). By the 16th century much of the 133 western wing of the castle was a disused ruin. The castle was partly dismantled in the 19th century.

Rywałd, located $7 \mathrm{~km}$ due East of Radzyń Chełmiński, is a rural site with evidence of woodland, and minor human impact within the pollen record of the same core during the 11th to 12th centuries (Brown et al., 2015). The surrounding area only was used within the past century 137 for agricultural purposes (Brown et al., 2015). The Vistula and Drwęca rivers are in proximity to 138 both sites. The Vistula River runs through the center of the Voivodeship which was once the 139 frontier zone between Slavic Pomeralia (East Pomerania), Prussian Pomesania, and Piast Poland 140 (Brown and Pluskowski, 2011; Pluskowski, 2013; Zamoyski, 1987). The underlying sediment is 141 made up of glacial till deposited by the Scandinavian ice sheet during the Vistulian (Weichselian) 142 Glaciation (receded 11,700 years ago; Marks, 2012).

\section{$144 \quad \underline{2.2}$ Sampling}

Two sediment cores, $100 \mathrm{~cm}$ (Radzyń Chełmiński) and $120 \mathrm{~cm}$ (Rywałd) depth, were 146 collected in August 2013 from the center of each wetland basin using a Russian auger. The

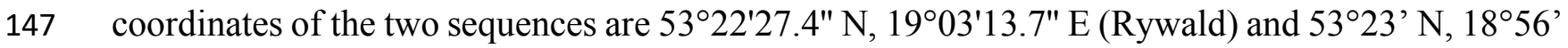

148 E (Radzyn). Sampling intervals were adjusted to obtain high-resolution records during the 149 Crusading Period and Teutonic Order occupation focused on the late medieval period ( $13^{\text {th }}$ to $16^{\text {th }}$ 150 centuries) based on age models derived from radiocarbon dating. For Radzyń Chełmiński and 151 Rywałd, 60 and 59 samples were considered, respectively. In March 2014, "background” samples 152 of glacial sediment at $100-200 \mathrm{~cm}$ depth below land surface were collected adjacent to both lakes 153 using a gouge auger to provide the natural background signature for each site. Four background 
154 samples for Radzyń were collected at Golebiewko, including 6 subsamples (N 53 degrees 23'39.

155 7" E 018 degrees 59'31. 1"). Three background samples for Rywałd were collected in Rywałd, 156 including 9 subsamples (N 53 degrees 20'58.5" E 019 degrees 05'22.0"). All samples were stored 157 at $4^{\circ} \mathrm{C}$ prior to analysis.

\subsection{Analyses}

Sediment cores were logged to determine macroscopic lithofacies. Mastersizer Laser analysis was used to specify particle size within each macro layer. Samples were collected every

$16210 \mathrm{~cm}$ for each lithofacies section. Samples were placed on a plastic crucible where a minimal amount of Calgon solution was added and mixed into sample with a rubber stamper until all

164 particles were separated. All organic material and particles above $2 \mathrm{~mm}$ were removed. The 165 solution was washed with ultra-pure water into the Mastersizer Laser for analysis.

167 with mortar and pestle prior to digestion. Aliquots of $500 \mathrm{mg}$ for each sample were transferred to 168 digestion tubes and cold digested at room temperature for 12 hours using $10 \mathrm{ml}$ ultra-high purity $169 \mathrm{HNO}_{3}$ under clean lab conditions. Tubes were moved to hot baths and heated at $60^{\circ} \mathrm{C}$ for three 170 hours, then at $110^{\circ} \mathrm{C}$ for an additional 12 hours. We wanted to extract metal deposition from the 171 sediments bound to organic matter, metal that had adhered to particles as a result of atmospheric 172 deposition and metals and elements bound to sediment surfaces. We did not want to digest all the 173 inorganic, silicate material as this leads to a much more complex $\mathrm{Pb}$ isotope signal with the 174 potential to mix from multiple geological sources. Studies have shown (Cook et al. 1997) that hot 175 HNO3 digestion delivers similar results to other digestion techniques as the bulk of the metal 
176 concentration is absorbed to the mineral surfaces and/or in organic matter, not in the mineral 177 silicate components. Digested samples were filtered using a $0.45 \mu \mathrm{m}$ filter and diluted to $100 \mathrm{ml}$ 178 in ultra-pure water for analysis. Reference materials (Sewage Reference 5RSS53) and full instrument blanks were included

180 for all analyses. In order to quantify the recovery rates from our digestion methods we used an 181 internal sewage sludge standard normalized against an international standard (ERM CC144), 182 which has reported values for extractable metals in sewage sludge. The reason we chose these 183 standards is that they have reported values for both total digestion and extractable metals (using 184 nitric acid), and have relatively high TOC (36 wt \%) which was similar to the peaty, organic 185 sediments from the core materials. The reported values for our internal standard (normalized to $186 \mathrm{ERM} \mathrm{CC144)} \mathrm{for} \mathrm{Pb}$ were $118 \mathrm{mg} / \mathrm{kg}$ and $8.8 \mathrm{mg} / \mathrm{kg}$ for Ti. The average of our extracted values 187 over four runs $(\mathrm{n}=8)$ were $128+/-13 \mathrm{mg} / \mathrm{kg}$ and $9.7+/-2.1 \mathrm{mg} / \mathrm{kg}$ for $\mathrm{Pb}$ and Ti respectively, 188 resulting in a recovery of $108+/-9 \%$ and $111+-18 \%$, respectively. This indicates that the nitric 189 acid extraction used was capable of liberating all of the available metal components in the organic 190 fraction.

192 Coupled Plasma - Optical Emission Spectrometer (ICP-OES) at the University of Reading, UK. 193 For each depth horizon, the enrichment factor (E.F.) for $\mathrm{Pb}$ was calculated using the equation (1) 194 provided below (Gloaguen and Passe, 2017; N'guessan et al., 2009) and average upper crustal Pb 195 and Ti concentrations (McLennan, 2001). Enrichment Factor quantifies the amount of enrichment 196 of Pb from natural levels within sediment (e.g. Chester and Stoner, 1973, N'guessan et al., 2009):

197

$$
E F=\frac{\left(\frac{P b}{T i}\right)_{\text {sample }}}{\left(\frac{P b}{T i}\right)_{\text {upper continental crust }}}
$$


To determine $\mathrm{Pb}$ isotopic compositions, digested samples were further diluted to $4 \mathrm{ppb}$ of $\mathrm{Pb}$ for each sample, based on individual $\mathrm{Pb}$ concentrations per sample as quantified by ICP-OES, to maintain the same concentration throughout samples. This was done so that $\mathrm{Pb}$ concentration 201 would not affect Pb isotope analysis. Reference NIST SRM 981 was used as the external standard 202 for ${ }^{206} \mathrm{~Pb},{ }^{207} \mathrm{~Pb}$, and ${ }^{208} \mathrm{~Pb}$ measurements. All analyses were run in bracket configuration (standard-

203 sample-standard) to allow for mass drift correction. Three $\mathrm{Pb}$ isotopes, namely ${ }^{206} \mathrm{~Pb},{ }^{207} \mathrm{~Pb}$, and $204{ }^{208} \mathrm{~Pb}$, were analyzed via Inductively Coupled Plasma - Mass Spectrometer (ICP-MS) 205 (ThermoFisher iCapQ) equipped with a collision cell. The external calibration standard NIST SRM 206981 was used to allow for mass drift correction. The mass drift for ${ }^{206} \mathrm{~Pb} /{ }^{207} \mathrm{~Pb}$ and ${ }^{208} \mathrm{~Pb} /{ }^{206} \mathrm{~Pb}$ were 207 routinely $<0.5 \%$. Two $\mathrm{Pb}$ isotope ratios were calculated: ${ }^{206} \mathrm{~Pb} /{ }^{207} \mathrm{~Pb}$ and ${ }^{208} \mathrm{~Pb} /{ }^{206} \mathrm{~Pb}$. These ratios 208 have been the most widely used in similar studies to determine anthropogenic inputs (e.g. Alfonso 209 et al., 2001, Bi et al., 2017, Díaz-Somoano et al., 2009, Monna et al., 2000,).

\section{$\underline{\text { 2.4 Sediment Dating }}$}

Accelerator Mass Spectrometry (AMS) ${ }^{14} \mathrm{C}$ dating was used to determine absolute age and 213 accumulation rates of sediment. Twelve samples were processed for Radzyń Chełmiński, at $10 \mathrm{~cm}$ 214 intervals, with 10 samples taken from Rywałd, at 5-15 cm intervals. Samples for radiocarbon 215 dating were sent to the Scottish Universities Research Centre (SUERC), Glasgow, Scotland. Linear 216 regression modelling was conducted using Bayesian accumulation to provide age-to depth 217 estimations through each core (SI_1; Bacon; Blaauw and Christen, 2011). To represent sediment 218 dates, the notation "A.D." was used for the age. 
Reliable chronologies are a fundamental component of palaeoecological investigation of lakes and peat bogs. Terrestrial plant macrofossils are considered the most reliable material for radiocarbon dating (Blaauw et al 2004), although unfortunately none were recovered from either

222 Radzyń or Rywałd. Radiocarbon dates were therefore derived on samples of gyttja (Radzyń) and 223 in the case of Rywałd on both peat and gyttja. Care was taken to identify any potential issues of 224 contamination with old or young. Contamination by young carbon may occur through root 225 penetration, whilst lake sediments may exhibit older radiocarbon ages (reservoir effect) reflecting 226 inclusion of old carbon eroded from calcareous soils/bedrock, or through the uptake of dissolved 227 inorganic carbon by aquatic plants (Björk and Wohlfarth 2004; Butz 2017). material for radiocarbon dating (e.g. Nilsson et al 2001; Blaauw et al 2004). The peat deposits 230 reflect treeless habitats, although some herbaceous plants growing in fens, such as sedges, have 231 root systems which can penetrate down to $2 \mathrm{~m}$, with the potential to introduce young carbon unless removed (e.g. Valiranta et al 2014). However, no roots or evidence for rooting by either trees or 233 herbaceous plants was recorded during the detailed examination and sampling of the cores.

The core from Radzyń was the final of three cores (Radzyń 3) sampled and analysed from 235 the Castle lake, with dates derived on gyttja (Radzyń 2 and Radzyń 3) and in the case of the first 236 Radzyń core (Radzyń 1) on both peat and gyttja. Although the occurrence and/or magnitude of a 237 reservoir effect can be difficult to determine without supporting dates from plant macrofossils or 238 lake varves, comparison between the four lake sequences from Radzyń and Rywałd suggest that if 239 present at all, the reservoir effect had a negligible effect on the chronologies. All four sequences 240 show a strong linear progression in radiocarbon dates. There is a high degree of temporal similarity 241 in pollen signals between sites, irrespective of whether dates are derived from peat or gyttja. 
242 Similarity is apparent in the timing of key changes in vegetation and land-use, most apparent in 243 the decline in hornbeam, and the onset of major anthropogenic activity from c. AD 1100 (Brown 244 2019); these changes are considered to reflect comparable local-regional processes, reflected with 245 varying magnitude in all four sequences from Radzyń and Rywałd. One could reasonably expect 246 to observe spatial and temporal variations in the magnitude of a reservoir effect, reflecting

247 variation in carbon input within and between sites and pollen sequences as a result of lake 248 catchment, vegetation and land-use (e.g. Tranvik et al 2009; Shou et al 2015) The high degree of 249 similarity therefore argues against a significant reservoir effect at Radzyń and Rywałd.

\section{$\underline{2.5}$ Modelling}

The Bayesian mixing model Food Reconstruction Using Isotopic Transferred Signals 253 (FRUITS; Fernandes et al., 2014) was run with our $\mathrm{Pb}$ isotope data $\left({ }^{206} \mathrm{~Pb} /{ }^{207} \mathrm{~Pb}\right.$ and $\left.{ }^{208} \mathrm{~Pb} /{ }^{206} \mathrm{~Pb}\right)$ 254 to model the anthropogenic contribution (in \% of total $\mathrm{Pb}$ ) versus time for both sites. Although 255 FRUITS was made for dietary reconstruction, it is a general mixing model suitable for 256 environmental isotopic modeling (e.g. Fernandes et al., 2014). FRUITS manual recommends to 257 not using too many sources vs proxies, no more than +1 (i.e. if you have 2 isotope ratios, you 258 shouldn't be asking FRUITS to attribute to more than 3 sources which is our case). For our 259 modeling, natural endmembers comprised the mean background values specific to each site. The 260 anthropogenic endmember for both sites was calculated from the mean of published Southwest 261 Poland coal, ore, and slag lead isotopic signatures (Tyszka et al., 2012). The dust endmember for 262 both sites was taken from Veron et al. (2014). 


\section{RESULTS}

\subsection{Sediment Characterization}

Troel-Smith core logging results show sediment at Radzyń Chełmiński is composed of 1)

267 highly humified Turfa herbacea and organic lake mud from 0 to $27 \mathrm{~cm}$ with a diffuse boundary;

268 2) organic lake mud with $10 \%$ to $1 \%$ roots from $27 \mathrm{~cm}$ to the bottom of the core. At Rywałd, 269 sediment is composed of 1) Argilla granosa: silt with roots to partially humified Turfa herbacea 270 peat from 0 to $43 \mathrm{~cm}$ with a sharp boundary; 2) silt and clay argilla with 5\% roots from 43 to 68 $271 \mathrm{~cm}$ with a sharp boundary; 3) organic lake mud composed of silty sand to sandy silt from $87 \mathrm{~cm}$ 272 to the bottom of the core (SI_2, SI_3).

274 size for both sites ranged from 0.46 to 3080 microns, ranging in grain size class from fine clay to 275 very fine gravel. The average grainsize at Radzyń Chełmiński was silt (55.56 to 62 microns) from 2760 to about $30 \mathrm{~cm}$, and very fine sand (62 microns to 104 microns) from $30 \mathrm{~cm}$ to the bottom of the 277 core. Percentages for clay, silt, and sand ranged from 0.67 to $3 \%, 50$ to $69 \%$, and 27 to $49 \%$, 278 respectively. At Rywałd all sediment was very fine sand (62 to 125 microns) apart from $42 \mathrm{~cm}$ 279 with an average particle size 126.25 microns (fine sand) (SI_4). Percentages for clay, silt, and sand ranged from 0.02 to $2 \%, 40$ to $61 \%$, and 23 to $50 \%$, respectively.

\section{$\underline{\text { 3.2 Lead Enrichment Factor and Isotopic Compositions }}$}

Radzyń Chełmiński and Rywałd profiles for $\mathrm{Pb}$ enrichment factor relative to average

284 continental crust (E.F.; McLennan, 2001), and ${ }^{206} \mathrm{~Pb} /{ }^{207} \mathrm{~Pb}$ are provided in Figure 2. Age values 285 are based on the average age modelled by $2 \sigma$ Bayesian modelled uncertainties. Lead is enriched 
by a factor of 14 to 60, and 13 to 159 for Radzyń Chełmiński and Rywałd, respectively. At Rywałd, there is a sharp decrease from $\sim 150$ at the top of the core to 75 around A.D. 1980, then further decrease to a minimum Pb E.F. of 37 around A.D. 1755 147 . Lead enrichment factor at Rywałd then varies between 33 and 70 down to A.D. $1104 \pm 80$, increases to the maximum E.F. of 159 around A.D. 1024 \pm 94 , and steadily decreases to 14 (A.D. $731 \pm 109$ ), where the Pb E.F. becomes relatively stable around $15 \pm 2$ to the bottom of the core (A.D. $572 \pm 8$ ). At Radzyń Chełmiński, Pb E.F. decreases from 81 at the top of the sediment core to 38 at A.D. $1621 \pm 166$, with a minor increase to 58 (A.D. $1587 \pm 148$ ) and continuing decrease to 30 at A.D. $1500 \pm 130$. Enrichment factor remains relatively stable with minor variations between 11 and 38 down to A.D. $979 \pm 102$, before decreasing to the minimum value of 14 at A.D. $894 \pm 85$, maintaining the same Pb E.F. until the bottom of the core (A.D. $803 \pm 99$ ).

For both sites, the ${ }^{206} \mathrm{~Pb} /{ }^{207} \mathrm{~Pb}$ ratio ranges from 1.17 to $1.27 \%$. At Radzyń Chełmiński, three zones can be defined. From the top of the core the ratio increases with age from $1.18 \%$ to $1.27 \%$ at A.D $1227 \pm 112$, then decreases to $1.18 \%$ at A.D. $934 \pm 97$. From this minimum, the ${ }^{206} \mathrm{~Pb} /{ }^{207} \mathrm{~Pb}$ ratio increases to $1.25 \%$ at the bottom of the core (A.D. $803 \pm 99$ ). Five ${ }^{206} \mathrm{~Pb} /{ }^{207} \mathrm{~Pb}$ zones can be identified for Rywałd. From the top of the core to A.D. $1443 \pm 114$, the isotopic ratio increases from $1.17 \%$ o to $1.21 \%$, then remains constant at $1.21 \pm 0.05 \%$ o down to A.D. $1395 \pm 68$. The ${ }^{206} \mathrm{~Pb} /{ }^{207} \mathrm{~Pb}$ ratio continues to increase to $1.25 \%$ at A.D. $1253 \pm 44$, decreases to $1.18 \%$ at A.D. $1083 \pm 82$, remains constant at $1.18 \%$ o to A.D. $768 \pm 106$, and significantly increases to $1.25 \%$ at A.D. $572 \pm 81$. These isotopic profiles are very different from those of previous published data of nearby sites from Northern Poland and Belgium (Fig. 2C; De Vleeschouwer et al., 2009b, Fagel et al., 2014), which show a similar trend to one another over time, with much lower and rather constant ${ }^{206} \mathrm{~Pb} /{ }^{207} \mathrm{~Pb}$ values $(1.14-1.18 \%$ ) than our new dataset. 
From the top of both cores to about A.D. 1700, as Pb E.F. decreases, the ${ }^{206} \mathrm{~Pb} /{ }^{207} \mathrm{~Pb}$ ratio increases. Lead E.F. and isotope ratios have a weak negative correlation, with higher Pb E.F.s coinciding with lower ${ }^{206} \mathrm{~Pb} /{ }^{207} \mathrm{~Pb}$ values.

\section{DISCUSSION}

\subsection{Identification of Lead Sources} $\mathrm{Pb}$ sources by comparing ${ }^{206} \mathrm{~Pb} /{ }^{207} \mathrm{~Pb}$ and ${ }^{208} \mathrm{~Pb} /{ }^{206} \mathrm{~Pb}$ ratios (Fig. 3; Alfonso et al., 2001, Bi et al., 2017, Díaz-Somoano et al., 2009, Harlavan et al., 2010, Monna et al., 2000, Zohar et al., 2014).

Background sample averages from both sites (natural $\mathrm{Pb}$ isotopic ratio endmember: Radzyń Chełmiński: ${ }^{206} \mathrm{~Pb} /{ }^{207} \mathrm{~Pb}=1.33 \pm 0.01 \%$; ${ }^{208} \mathrm{~Pb} /{ }^{206} \mathrm{~Pb}=1.97 \pm 0.004 \%$; Rywałd: ${ }^{206} \mathrm{~Pb} /{ }^{207} \mathrm{~Pb}=$ $1.30 \pm 0.02 \% ;{ }^{208} \mathrm{~Pb} /{ }^{206} \mathrm{~Pb}=1.96 \pm 0.03 \%$ ) and Southwest Poland coal, ore, and slag combined 321 average (anthropogenic endmember: ${ }^{206} \mathrm{~Pb} /{ }^{207} \mathrm{~Pb}=1.17 \pm 0.01 \%$ and ${ }^{208} \mathrm{~Pb} /{ }^{206} \mathrm{~Pb}=2.09 \pm 0.01 \%$; 322 Tyszka et al., 2012) were also included in Figure 3. Lead isotopic ratios for both Radzyń 323 Chełmiński fall along a single trend line between the anthropogenic endmember and an 324 endmember similar to the background averages. Due to the glacial till composition of background 325 sediment, $\mathrm{Pb}$ isotopic ratios for samples are not perfectly linear with background ratios. Overall, 326 the ${ }^{206} \mathrm{~Pb} /{ }^{207} \mathrm{~Pb}$ ratio ranges from 1.18 to $1.28 \%$ for Radzyń Chełmiński, and 1.17 to $1.25 \%$ for 327 Rywałd. The ${ }^{208} \mathrm{~Pb} /{ }^{206} \mathrm{~Pb}$ ratio for Radzyń Chełmiński ranges from 1.96 to 2.08\%, and 1.98 to $3282.10 \%$ for Rywałd. Error bars representing 1 standard deviation for all averages are included 329 (Southern Poland coal, ore and slag ${ }^{206} \mathrm{~Pb} /{ }^{207} \mathrm{~Pb}=1.17 \pm 0.01 ;{ }^{208} \mathrm{~Pb} /{ }^{206} \mathrm{~Pb}=2.09 \pm 0.01$; Radzyń 
Chełmiński background ${ }^{206} \mathrm{~Pb} /{ }^{207} \mathrm{~Pb}=1.33 \pm 0.01 ;{ }^{208} \mathrm{~Pb} /{ }^{206} \mathrm{~Pb}=1.97 \pm 0.004$; Rywałd background $\left.{ }^{206} \mathrm{~Pb} /{ }^{207} \mathrm{~Pb}=1.30 \pm 0.03 ;{ }^{208} \mathrm{~Pb} /{ }^{206} \mathrm{~Pb}=1.96 \pm 0.03\right)$.

Compared to other similarly aged Central European sedimentary records, our new dataset displays significant differences (e.g. Fagel et al., 2014, Zillen et al., 2012, De Vleeschouwer et al., 2009b). Previously published data from the North Poland Bog (Słowińskie Błoto Bog; De Vleeschouwer et al., 2009b) fall along the same trend line. However, the North Poland bog displays an isotopic composition almost entirely from Southwest Poland coal and ore, indicating a much stronger regional anthropogenic signal, with little to no natural $\mathrm{Pb}$ input as indicated in the previous study (Fig. 3; De Vleeschouwer et al., 2009b). In addition, the North Poland Bog indicates an entirely anthropogenic source, with lower ${ }^{206} \mathrm{~Pb} /{ }^{207} \mathrm{~Pb}$ and ${ }^{208} \mathrm{~Pb} /{ }^{206} \mathrm{~Pb}$ than that of the Southwest Poland anthropogenic end members. Such source dissimilarity is expected. Unlike Radzyń Chełmiński and Rywałd, Słowińskie Błoto is a raised (ombrotrophic) peat bog. Signals from peat sediment are expected to record mostly atmospheric inputs (solely rain), versus lake sediment from the current study which include both terrestrial sediment (from runoff) and atmospheric inputs (e.g. Fagel et al., 2014, Thevenon et al., 2011).

\subsection{Changes in Lead Sources Over Time}

\subsubsection{Anthropogenic Sources}

Lead isotopic data processed using FRUITS, a Bayesian mixing model, quantified the importance of anthropogenic $\mathrm{Pb}$ inputs for each depth sampled (Fig. 4). Climatic periods included in bars below both graphs present cold periods as blue bars, and warm periods as red bars. Arrows along the top of Figure 4 indicate the building of a Teutonic Order fort (A.D. 1234; Urban, 1980) 
352 and castle (late $13^{\text {th }}$ century; Urban, 1980) at Radzyń Chełmiński; this activity would not have 353 impacted Rywałd.

Modeled anthropogenic $\mathrm{Pb}$ contribution is described from oldest to most recent inputs (Fig. 4). At Radzyń Chełmiński, the fraction of total lead attributed to anthropogenic inputs in the oldest

356 sediments appears to be influenced by anthropogenic $\mathrm{Pb}$ pollution from A.D. $883 \pm 99$ to A.D. 357 1054 \pm 104 . Contribution of Southwest Poland coal, ore, and slag during that period reaches a maximum of $35 \%$ at A.D. $979 \pm 97$. The anthropogenic fraction of total $\mathrm{Pb}$ remains below $1 \%$ from A.D. $1168 \pm 114$ to with A.D. $1296 \pm 94$, then increases from the beginning of the 14 th century towards a dominantly anthropogenic contribution at the top of the core (up to 65\%).

At Rywałd, the modeled anthropogenic contribution increases from the core bottom to reach a maximum in A.D. $973 \pm 80$ of $65 \%$, and decrease to $1 \%$ at A.D. $1223 \pm 45$. Subsequently, the contribution sharply increases to $49 \%$ in A.D. $1303 \pm 54$ and remains relatively stable with an average value of $38 \pm 8 \%$ to the top of the core, with the exceptions of the two most recent samples 365 (74 and 86\%).

\subsubsection{Mining Activity - Long Range Transport}

Atmospheric anthropogenic $\mathrm{Pb}$ signatures are expected to have been transported from regional mines. Approximately $400 \mathrm{~km}$ to the south of Radzyń Chełmiński and Rywałd, in the

370 Rudawy Janowickie Mountains of Southwest Poland, a series of mines were active periodically 371 over the last millennium (e.g. Kierczak and Pietranik, 2011). Primary ores from Southwest Poland 372 include bituminous and brown coal, $\mathrm{Cu}, \mathrm{Zn}$, and $\mathrm{Pb}$ ores, native $\mathrm{S}$, and rock salt (Rybicka, 1996). 373 Samples from Janowice, Wielkie, Szklary, Legnica, Miedzianka, and Wałbrzych sites in 
374 Southwest Poland were used to represent an anthropogenic contribution (Fig. 4; Tyszka et al.,

375 2012). These mines are the nearest likely source of anthropogenic $\mathrm{Pb}$ in sediments from both

376 Radzyń Chełmiński and Rywałd. Documentation and precise dates are scarce prior to the 1800s,

377 but evidence can be pieced together through the few historical records available and archaeological

378 evidence.

379

First known $\mathrm{Zn}-\mathrm{Pb}$ ore exploitation in Southwest Poland began in the Cracow-Silesia district during the $12^{\text {th }}$ to $13^{\text {th }}$ centuries (Cabala et al., 2013). Mining and smelting of $\mathrm{Cu}$ in the

381 Rudawy Janowickie Mountains has occurred from the $14^{\text {th }}$ century to present (e.g. Bukowski, 382 2011, Kierczak et al., 2013). Miedzianka, in particular was the largest center of mining and 383 smelting $\mathrm{Cu}$, As, and $\mathrm{Ag}$ in Silesia, beginning as early as A.D. 1310 (Kierczak and Pietranik, 384 2011). These mining activities are probably responsible for the change in $\mathrm{Pb}$ isotopic ratios 385 observed at Rywałd just after A.D. 1200 (Fig. 4). Copper slags were deposited in the mountains 386 from the $14^{\text {th }}$ to $16^{\text {th }}$ century (Kierczak et al., 2013). Exploitation peaked in the $16^{\text {th }}$ century, when 387 resources were exhausted, declining until the end of the $17^{\text {th }}$ century (Kierczak and Pietranik, 388 2011). Our data indicates that this historical record of mining activity resulted in lead pollution 389 throughout the region, as shown by the relatively stable anthropogenic contribution in Rywałd for 390 the same time period followed by a small decrease. Ore mining activities became prevalent again 391 from the beginning of the $18^{\text {th }}$ century to the beginning of the $19^{\text {th }}$ century, focusing on Cu-rich 392 ore, as anthropogenic $\mathrm{Pb}$ again increases at Rywałd. Mining and smelting in the Rudawy 393 Janowickie mountains ceased entirely in A.D. 1925 (Kierczak and Pietranik, 2011, Kierczak et al., 394 2013).

Coal exploitation was also prevalent in the Rudawy Janowickie Mountains of Southwest

396 Poland from the $12^{\text {th }}$ century onwards, including two key basins, the Upper Silesian Coal Basin 
(Bukowski, 2011, Rybicka, 1996) and the Lower Silesian Coal Basin (LSCB; Rybicka, 1996). Ore was also mined in these basins. In Bytom and Olkusz, sub districts of the Upper Silesian Coal Basin, $\mathrm{Pb}, \mathrm{Zn}$, and $\mathrm{Cd}$ ores were mined since the $12^{\text {th }}-14^{\text {th }}$ century (depending on source; Ciarkowska et al., 2016, Rybicka, 1996,).

Additionally, from the 1800s onwards, anthropogenic contributions from modern mining, bituminous coal combustion, and leaded gasoline exerted substantial control of the sedimentary $\mathrm{Pb}$ isotopic compositions and concentrations at both sites, as documented in previous studies (e.g. De Vleeschouwer et al., 2009b, Fialkiewicz-Koziel et al., 2018).

To test our hypothesis, a simple mass-balance calculation was applied. At Radzyn by considering only the first $60 \mathrm{~cm}$ with a bulk density of approximately $1000 \mathrm{~kg} / \mathrm{m}^{3}$, where a mean increase in total $\mathrm{Pb}$ of about 5-10 ppm above baseline values can be observed, and by simplifying the time required to accumulate these sediments to 1000 years, we can estimate an average deposition rate of 3-6 mg.m $\mathrm{m}^{-2} \mathrm{y}^{-1}$. Considering this range of deposition rate, we cannot exclude influences from other sources either local or distant.

\subsubsection{Land Use within Castle Lake Watershed - Short Range Transport}

Earliest palynological records at Radzyń Chełmiński suggest the region was dominated by woodland with evidence of local small-scale agricultural activities present around A.D. 0-700 (Brown et al., 2015). The Wielbark culture was present in the area from the $2^{\text {nd }}$ to the $5^{\text {th }}$ century A.D., during the Migration period (A.D. 300 to 700 ). The $5^{\text {th }}$ to $9^{\text {th }}$ century is marked by archaeological evidence of tumuli and stone graves in the forest surrounding Radzyń Chełmiński, with remains of a Slavonic settlement adjacent to the forest (Samojlik et al., 2013). There is also 
419 archaeological evidence of depopulation from the $4^{\text {th }}$ century until Slavic settlement from the $7^{\text {th }}$ 420 century (Buko, 2008). A Slavic stronghold was constructed in proximity to Castle Lake around the 421 late $9^{\text {th }}$ century (e.g. Urban, 1980). controlled by a Slavic Stronghold, occupied from the late $9^{\text {th }}$ to $\mathrm{mid} 12^{\text {th }}$ century when it may have

424 been burnt down in an attack (Brown et al., 2015, Chudziak, 1994). Concurrently, there was an 425 intensification in agricultural activity and decrease in woodland, causing increased soil erosion 426 into the surrounding wetland, as presented by palynological evidence (Brown et al., 2015; 427 Chudziak, 1996). Such erosion and increased land-use may have contributed to a decrease in 428 recorded anthropogenic contribution and $\mathrm{Pb}$ concentration at Radzyń Chełmiński. Palynological 429 evidence describes an increasingly open landscape in the pre-Crusading period $\left(11^{\text {th }}\right.$ to $12^{\text {th }}$ 430 century) of both intensifying arable and pastoral activity, with woodland retained on nearby land 431 (Brown et al., 2015). 433 when the Order ceded the territory to Polish control (Pluskowski, 2013; Urban, 1980). The 434 Crusading period began in A.D. 1230, concurrent with the founding of the Teutonic Order castle 435 and town at Radzyń Chełmiński (Brown et al., 2015). During this period agricultural and pastoral 436 land-use was relatively stable surrounding the Castle Lake (Brown et al., 2015). A timber fort was 437 constructed in A.D. 1234, and the castle was later built between A.D. 1310 and 1340 (e.g. Brown 438 et al., 2015). Previously published palynological evidence from Radzyń Chełmiński recorded 439 changes in vegetation and land use during this period, including a decrease in arboreal pollen and 440 increase in cereal pollen (Brown and Pluskowski, 2011; Pluskowski, 2013). The period between 441 A.D. 1350 and 1400 is known as the "Golden Age" of Teutonic Order influence (e.g. Pluskowski, 
442

443

444

445

446

447

448

449

450

451

452

453

454

455

456

457

458

459

460

461

462

463

464
2013). Heathland developed along with agricultural intensification from the late $14^{\text {th }}$ to $15^{\text {th }}$ century, accompanied by a decrease in woodland area (Brown and Pluskowski, 2011). In addition to landscape changes with the arrival of the Teutonic Order, trade routes also developed by efforts to exploit Prussian resources, adding to human impact from the nearby settlements (Harte and Ponting, 1983). As the frontier land between Teutonic Order Prussia and Poland, the Chełmo land (Kulmerland in German), including Radzyń Chełmiński and Rywałd experienced intermittent raids from Prussian tribes, including the Great Prussian Uprising of the 1260s, and subsequent transformation of the landscape (Lukowski and Zawadzki, 2001; Pluskowski, 2013). Such agricultural intensification and castle building may have contributed to altered the regional anthropogenic isotopic signal from the opening of mines within the sediment records, minimizing the expected increase in anthropogenic $\mathrm{Pb}$ contribution that was detected at Rywałd, while at the same time causing an increase in $\mathrm{Pb}$ concentration.

In A.D. 1410, Radzyń Chełmiński Castle was damaged by Polish-Lithuanians (e.g. Pluskowski, 2013). From A.D. 1412 to 1439, the surrounding landscape was subjected to multiple seasons of crop failure, causing many villages in the area to be covered by woodland by A.D. 1444 . The Thirteen Years war occurred shortly after, from A.D. 1453 to 1466, with many conflicts occurring near Radzyń, after which the castle became occupied by Poland (e.g. Pluskowski, 2013), falling into ruin by the $16^{\text {th }}$ century (Brown et al., 2015). Further damage occurred during the Swedish Invasion from A.D. 1626 to 1629 (e.g. Brown et al., 2015). Wooded areas contribute minimal weathered and eroded sediment to the surrounding basin, compared to predominantly open fields (arable and pastoral land). The decrease in local influence from the nearby castle and town, and re-establishment of woodlands, may have allowed for a return to a predominantly regional, atmospheric $\mathrm{Pb}$-derived signal in the sediment record during this period. 


\subsubsection{Regional Climatic Influence}

Differentiating between climatic and historical influences remains challenging. Although

468

469

470

471

472

473

474

475

476

477

478

479

480

481

482

483

484

485

486

$\mathrm{Pb}$ isotopes are not climate proxies, it is possible climate change or influencing meteorological conditions (e.g. change in dominant wind direction patterns, increase in rainfall, flood events, etc.) might indirectly influence $\mathrm{Pb}$ isotopic signatures by promoting the development of human activities (e.g. Büntgen et al., 2016, 2011), mostly during warmer and dryer periods. According to our sediment data (SI_2, SI_3), the Radzyń Chełmiński core is made entirely of lake $\mathrm{mud} / \mathrm{sediment}$; while Rywałd contains peat sediment from 0 to $68 \mathrm{~cm}$, and lake mud/sediment from $68 \mathrm{~cm}$ to the bottom of the core.

Sedimentary records for both cores span five climatic periods: 1) Late Antique Little Ice Age (LALIA, A.D. 536 to 660; e.g. Berglund et al., 2003; Büntgen et al., 2016); 2) the Climatic Optimum in Prussia (COP, A.D. 800 to 1150; e.g. Pluskowski, 2013); 3) the Medieval Warm Period (MWP; A.D. 800 to 1300; e.g. De Vleeschouwer et al., 2009b); 4) the Little Ice Age (LIA; A.D. 1300 to 1850; e.g. De Vleeschouwer et al., 2009b; Hegerl et al., 2017; Lockwood, 2001); and 5) Global Warming (GW; A.D. 1890 to present; e.g. Chiriloaei et al., 2012; Hegerl et al., 2017). Unlike in Western Europe, Prussian communities did not experience a regression after the medieval warm period, and instead thrived (Pluskowski, 2013). We hypothesize that promotion of human activities during favorable climatic conditions (Büntgen et al., 2016) included behaviors that mobilize lead, such as coal burning and ore utilization.

\section{CONCLUSION}


In this study, $\mathrm{Pb}$ concentrations and isotope ratios were used to quantify anthropogenic lead 488 inputs and sources, as well as to identify trends in human activity in Northern Poland over the last 4891,500 years. The use of a rural lake sediment core at Rywałd and a lake core influenced by a nearby 490 town and Teutonic Order castle at Radzyń Chełmiński enabled differentiation between local and 491 regional anthropogenic inputs.

Two primary $\mathrm{Pb}$ sources have been identified: (1) coal, ore, and slag originated from

493 Southwestern Poland mining activities (long range transport); and (2) erosion from the surrounding 494 watershed associated with the development of human activities (short range transport). High 495 anthropogenic $\mathrm{Pb}$ contributions from the 9th to 11th centuries A.D., in the absence of historical 496 evidence for mining activity in Southwestern Poland, point to a previously-unrecognized, 497 substantial anthropogenic $\mathrm{pb}$ source during that time period. Local activities dominated the $\mathrm{Pb}$ 498 isotopic record from the $11^{\text {th }}$ to $13^{\text {th }}$ centuries A.D., during periods of Slavic and subsequent 499 Teutonic Order settlement and castle building, and agricultural intensification. The long range, 500 anthropogenic, mining signal was elevated around the $16^{\text {th }}$ and $18^{\text {th }}$ to $19^{\text {th }}$ centuries A.D., during 501 periods of decreased local human agricultural activity.

Overall, the sediments at Rywałd recorded mostly long range mining inputs originating 503 from Southwest Poland, while Radzyń Chełmiński sediments recorded both sources long range 504 mining signal and local signal from an increase in agricultural and other human activities related 505 to the development of the town and castle. Further studies are required to identify the sources 506 responsible for the anthropogenic signal observed for our sites prior to A.D. 1000. 
The research leading to the results has received funding from the European Union's

510 Seventh Framework Programme (FP7/2007-2013) under grant agreement no. 263735, The

511 Ecology of Crusading. A.C. thanks the U.S. National Science Foundation (Award EAR-1503596)

512 for funding this research. A.C. acknowledges the Donors of the American Chemical Society

513 Petroleum Research Fund (ACS-PRF 54583-DNI2) for supporting this research. We thank two

514 anonymous reviewers for their constructive comments.

515

\section{REFERENCES}

517 Alfonso, S., Grousset, F., Masse, L., \& Tastet, J., 2001. A European lead isotope signal recorded 518 from 6000 to 300 years BP in coastal marshes (SW France). Atmospheric Environment. 35, 519 3595-3605. https://doi.org/10.1016/s1352-2310(00)00566-5

520 Audry, S., Pokrovsky, O.S., Shirikova, L.S., Kirpoten, S.N., Dupre, B., 2011. Organic matter 521 mineralization and trace element post-depositional redistribution in Western Siberia 522 thermokarst lake sediments. Biogeosciences. 8, 3341-3358. https://doi.org/10.5194/bgd-8$523 \quad \underline{8845-2011}$

524 Baron, S., Carignan, J., Ploquin, A., 2006. Dispersion of Heavy Metals (Metalloids) in Soils from 525 800-Year-Old Pollution (Mont-Lozere, France). Environ. Sci. Technol. 40, 5319-5326. 526 https://doi.org/10.1021/es0606430

527 Berglund, B.E., 2003. Human Impact and climate changes - synchronous events and a causal link? Quaternary International. 105, 7-12. https://doi.org/10.1016/s1040-6182(02)00144-1 
529 Bi, X.-Y., Li, Z.-G., Wang, S.-X., Zhang, L., Xu, R., Liu, J.-L., Yang, H.-M., Guo, M.-Z., 2017. Lead

530

531

532

533 534

535

536

537

538

539 Blaauw, M., Christen, J.A., 2011. Flexible Paleoclimate Age-Depth Models Using an Autoregressive

540 Gamma Process. Bayesian Analysis. 6, 3, 457-474. https://doi.org/10.1214/11-BA618

Isotopic Compositions of Selected Coals, $\mathrm{Pb} / \mathrm{Zn}$ Ores and Fuels in China and the Application for Source Tracing. Environmental Science \& Technology. 51, 13502-13508. https://doi.org/10.1021/acs.est.7b04119

Bjőrck S., Wohlfarth, D., 2002. 14C chronostratigraphic techniques in paleolimnology, in: Smol J.P., Birks H.J.B., Last W.M., (eds.) Tracking Environmental Change Using Lake Sediments, vol 1.Kluwer Academic Publishers, Dordrecht, pp. 205-245.

raised bogs: non-existence of a previously reported 'reservoir effect'. Quat. Sci. Rev. 23, 1537-1542.

541 Brown, A., Pluskowski, A., 2011. Detecting the environmental impact of the Baltic Crusades on a

542

543

544

545 Brown, A., Banerjea, R. Wynne, AD, Stivrins, N., Jarzebowski, M., Shillito, L-M., Pluskowski, A., 546

547

548

549 late-medieval (13th-15th century) frontier landscape: palynological analysis from Malbork Castle and hinterland, Northern Poland. Journal of Archaeological Science. 38(8), 19571966. https://doi.org/10.1016/j.jas.2011.04.010 2015. The ecological Impact of conquest and colonization on a Medieval Frontier Landscape: Combined Palynological and Geochemical Analysis of Lake Sediments from Radzyń Chełmiński, Northern Poland. Geoarchaeology: An International Journal. 30, 511-527. https://doi.org/10.1002/gea.21525 
550 Brown, A., 2019. Vegetation changes in Prussia: the palynological data. In A.G. Pluskowski (ed.) 551 Environment, Colonisation, and the Crusader States in Medieval Livonia and Prussia. $552 \quad$ Brepols.

553 Buko, A., 2008. The archaeology of early medieval Poland: Discoveries - hypotheses $554 \quad$ interpretations. Leiden: Brill.

555 Bukowski, P., 2011. Water Hazard Assessment in Active Shafts in Upper Silesian Coal Basin Mines. 556 Mine Water Environ. 30, 302-311. https://doi.org/10.1007/s10230-011-0148-2

557 Büntgen, U., Myglan, V.S., Ljungqvist, F.C., McCormick, M., Cosmo, N.D, Sigl, M., Jungclaus, J., 558 Wagner, S., Krusic, P.J., Esper, J., Kaplan, J.O., de Vaan, M.A.C., Luterbacher, J., Wacker, 559 L., Tegel, W., Kirdyanov, A.V., 2016. Cooling and societal change during the Late Antique 560 Little Ice Age from 536 to around 660 AD. Nature Geoscience. 9, 231-236. 561 https://doi.org/10.1038/ngeo2652

562 Büntgen, U., Tegel, W., Nicolussi, K., McCormick, M., Frank, D., Trouet, V., Kaplan, J.O., Herzig, 563 F., Heussner, K.-U., Wanner, H., Luterbacher, J., Esper, J., 2011. 2500 Years of European 564 Climate Variability and Human Susceptibility. Science, 331, 578-582. $565 \quad$ https://doi.org/10.1126/science.1197175

566 Butz, C., Grosjean, M., Goslar, T., et a., 2017. Hyperspectral imaging of sedimentary bacterial 567 pigments: a 1700-year history of meromixis from varved Lake Jaczno, northeast Poland. J.

$568 \quad$ Palaeolimnol. 58, 57-72. 
569 Cabala, J. Smieja-Krol, B., Jablonska, M., Chrost, L., 2013. Mineral components in a peat deposit: $570 \quad$ looking for signs of early mining and smelting activities in Silesia-Cracow region (Southern 571 Poland). Environ. Earth Sci. 69, 2559-2568. https://doi.org/10.1007/s12665-012-2080-6

572 Cheng, H., Hu, Y., 2010. Lead (Pb) isotopic fingerprinting and its applications in lead pollution 573 studies in China: A review. Environmental Pollution. 158,5, 1134-1146. $574 \quad$ https://doi.org/10.1016/j.envpol.2009.12.028

575 Chester, R., Stoner, J.H., 1973. Pb in particulates from the lower atmosphere of the eastern Atlantic. $576 \quad$ Nature. 24, 27-28. https://doi.org/10.1038/245027b0

577 Chiriloaei, F., Rădoane, M., Perşoiu, I., Popa, I., 2012. Late Holocene history of Moldova River 578 Valley, Romania. Catena. 93, 64-77. https://doi.org/10.1016/i.catena.2012.01.008

579 Chudziak, W., 1996. Zasiedlenie strefy chełmin' sko-dobrzyn' skiej we wczesnym s'redniowieczu $580 \quad$ (VII-XI wiek). Torun': UMK.

581 Ciarkowska, K., Gargiulo, L., Mele, G., 2016. Natural restoration of soils on mine heaps with similar 582 technogenic parent material: A case study of long-term soil evolution in Silesian-Krakow 583 Upland Poland. Geoderma. 261, 141-150. https://doi.org/10.1016/j.geoderma.2015.07.018

584 Cook, J.M., Gardner, M.J., Griffiths, A.H., Jessop, M.A., Ravenscroft, J.E. and Yates, R. (1997) The 585 comparability of sediment digestion techniques for the determination of metals in sediments. $586 \quad$ Marine Pollution Bulletin, 34(8), 637-644.

587 De Vleeschouwer, F., Piotrowska, N., Sikorski, J., Pawlyta, J., Cheburkin, a., Le Roux, G., 588 Lamentowicz, M., Fagel, M., Mauquoy, D., 2009a. Multiproxy evidence of 'Little Ice Age’ 
palaeoenvironmental changes in a peat bog from northern Poland. The Holocene. 19, 4, 625-

591 De Vleeschouwer, F., Fagel, N., Cheburkin, A., Pazdur, A., Sikorski, J., Mattielli, N., Renson, V., 592 Fialkiewicz, B., Piotrowska, N., Le Roux, G., 2009b. Anthropogenic impacts in North Poland 593 over the last 1300 years - A record of $\mathrm{Pb}, \mathrm{Zn}, \mathrm{Cu}, \mathrm{Ni}$ and $\mathrm{S}$ in an ombrotrophic peat bog. 594 Science of the Total Environment. 407(21), 5674-5684. $595 \quad$ https://doi.org/10.1016/j.scitotenv.2009.07.020

596 Díaz-Somoano, M., Kylander, M.E., López-Antón, M.A., Suárez-Ruiz, M.R., Martínez-Tarazona, 597 M., Ferrat, Kober, B., Weiss, D.J., 2009. Stable Lead Isotope Compositions In Selected Coals 598 From Around The World And Implications For Present Day Aerosol Source Tracing. $599 \quad$ Environ. Sci. Technol. 43, 1078-1085.

600 Doe, B. R., 1970. Lead isotopes. Springer Verlag, Berlin, Heidelberg, New York. $601 \quad$ https://doi.org/10.1007/978-3-642-87280-8

602 Fagel, N., Allan, M., Le Roux, G., Mattielli, N. Piotrowska, N., Sikorski, J., 2014. Deciphering 603 human-climate interactions in an ombrotrophic peat record: $\mathrm{REE}, \mathrm{Nd}$ and $\mathrm{Pb}$ isotope 604 signatures of dust supplies over the last 2500years (Misten bog, Belgium). Geochimica et 605 Cosmochimica Acta. 135, 288-306. https://doi.org/10.1016/j.gca.2014.03.014

606 Fernandes, R., Millard, A. R., Brabec, M., Nadeau, M.-J., \& Grootes, P., 2014. Food Reconstruction 607 Using Isotopic Transferred Signals (FRUITS): A Bayesian Model for Diet 608 Reconstruction. PLoS ONE. 9,2. https://doi.org/10.1371/journal.pone.0087436 
609 Fiałkiewicz-Kozieł, B., De Vleeschouwer, F., Mattielli, N., Fagel, N., Palowski, B., Pazdur, A., 610 Smieja-Król, B., 2018. Record of Anthropocene pollution sources of lead in disturbed

611 peatlands from Southern Poland. Atmospheric Environment. 179, 61-68. $612 \quad \underline{\text { https://doi.org/10.1016/j.atmosenv.2018.02.002 }}$

613 Flegal, A.R., Smith, D.R., 1995. Measurements of environmental lead contamination and human 614 exposure. Reviews of Environmental Contamination and Toxicology. 143, 1-45. $615 \quad$ https://doi.org/10.1007/978-1-4612-2542-3_1

616 Gallon, C., Tessier, A., Gobeil, C., Afaro-De La Torre, M. C., 2004. Modeling diagenesis of lead in 617 sediments of a Canadian Shield Lake. Geochimica et Cosmochimica Acta. 68, 17, 3531-3545. $618 \quad$ https://doi.org/10.1016/j.gca.2004.02.013

619 Grousset, F.E., Quetel, C.R., Thomas, B., Buatmenard, P., Donard, O.F.X., Bucher, A., 1994. 620 Transient $\mathrm{Pb}$ Isotopic Signatures in the Western-European Atmosphere. Environ. Sci. 621 Technol. 28, 9, 1605-1608. https://doi.org/10.1021/es00058a011

622 Harlavan, Y., Erel, Y., Blum, J. D., 1998. Systematic Changes in Lead Isotopic Composition with 623 Soil Age in Glacial Granitic Terrains. Geochimica et Cosmochimica Acta. 62,1, 33-46. $624 \quad$ https://doi.org/10.1016/s0016-7037(97)00328-1

625 Harlavan, Y., Almogi-Labin, A., Herut, B., 2010. Tracing Natural and Anthropogenic Pb in 626 Sediments along the Mediterranean Coast of Israel using Pb Isotopes. Environ. Sci. Technol. 627 44, 6576-6582. https://doi.org/10.1021/es9039055 
628 Harte, N.B. \& Ponting, K.G. (Eds), 1983. Cloth and Clothing in Medieval Europe: Essays in Memory 629 of Professor E.M. Carus-Wilson. Heinemann Educational Books Ltd., London.

630 Hegerl, G. C., Brönnimann, S., Schurer, A., Cowan, T., 2017. The early 20th century warming: 631 Anomalies, causes, and consequences. WIREs Clim. Change. 9, e522. 632 https://doi.org/10.1002/wcc.522.

633 Hosono, T., Alvarez, K., Kuwae, M., 2016. Lead isotope ratios in six lake sediment cores from Japan 634 Archipelago: Historical record of trans-boundary pollution sources. Science of the Total 635 Environment. 559, 24-37. https://doi.org/10.1016/j.scitotenv.2016.03.138

636 Huerta-Diaz, M. A., Tessier, A., Carignan, R., 1998. Geochemistry of trace metals associated with 637 reduced sulfur in freshwater sediments, Applied Geochemistry. 13, 213-233. $638 \quad$ https://doi.org/10.1016/s0883-2927(97)00060-7

639 Kierczak, J., Pietranik, A., 2011. Mineralogy and composition of historical Cu Slags from the 640 Rudawy Janowickie Mountains, Southwestern Poland. The Canadian Mineralogist. 49, 1281641 1296. https://doi.org/10.3749/canmin.49.5.1281

642 Kierczak, J., Potysz, A., Pietranik, A., Tyszka, R., Modelska, M., Néel, C., Ettler, V., Mihaljevič, 643 M., 2013. Environmental impact of the historical $\mathrm{Cu}$ smelting in the Rudawy Janowickie 644 Mountains (south-western Poland). J. Geochemical Exploration. 124, 183-194. 645 https://doi.org/10.1016/j.gexplo.2012.09.008 
646 Komárek, M., Ettler, V., Chrastný, V., Mihaljevič, M., 2008. Lead isotopes in environmental 647 sciences: A review. Environment International. 34, 4, 562-577. $648 \quad$ https://doi.org/10.1016/j.envint.2007.10.005

649 Kylander, M., Weiss, D., Martinezcortizas, A., Spiro, B., Garciasanchez, R., Coles, B., 2005. 650 Refining the pre-industrial atmospheric $\mathrm{Pb}$ isotope evolution curve in Europe using an 8000 651 year old peat core from NW Spain. Earth and Planetary Science Letters. 240, 2, 467-485. $652 \quad$ https://doi.org/10.1016/j.eps1.2005.09.024

653 Lanphear, B.P., Hornung, R., Khoury, J., Yolton, K., Baghurst, P., Bellinger, D.C., Canfield, R.L., 654 Dietrich, K.N., Bornschein, R., Greene, T., Rothenberg, S.J., Needleman, H.L., Schnaas, L., 655 Wasserman, G., Graziano, J., Roberts, R., 2005. Low-Level Environment Lead Exposure and 656 Children's Intellectual Function: An International Pooled Analysis. Environmental Health $657 \quad$ Perspectives, 113, 7, 894-899.

658 Lockwood, J.G., 2001. Abrupt and sudden climatic transitions and fluctuations: A Review. Int. J. 659 Climatol. 21, 9, 1153-1179. https://doi.org/10.1002/joc.630.abs

660 Lukowski, J. \& Zawadzki, H., 2001. A Concise History of Poland. Cambridge University Press, $661 \quad$ Cambridge. https://doi.org/10.1017/cbo9780511813856

662 Marks, L., 2012. Timing of the Late Vistulian (Weichselian) glacial phases in Poland. Quaternary 663 Science Reviews. 44, 81-88. https://doi.org/10.1016/j.quascirev.2010.08.008

664 Martínez Cortizas, A., García-Rodeja, E., Pontevedra Pombal, X., Nóvoa Muñoz, J.C., Weiss, D., 665 Cheburkin, A., 2002. Atmospheric Pb deposition in Spain during the Last 4600 years recorded 

Environ. 292, 33-44.

668 Martínez Cortizas, A., López-Merino, L., Bindler, R., Mighall, T., Kylander, M.E., 2016. Early 669 atmospheric metal pollution provides evidence for Chalcolithic/Bronze Age mining and 670 metallurgy in Southwestern Europe. Sci. Total. Environ. 545-546, 398-406. 671 http://dx.doi.org/10.1010/j/scitotenv.2015.12.078

672 McIntyre, A.M., Gueguen, C., 2013. Binding interactions of algal-derived dissolved organic matter 673 with metal ions. Chemosphere.

90 620-626. https://doi.org/10.1016/j.chemosphere.2012.08.057

675 McLennan, S.M., 2001. Relationships between the trace element composition of sedimentary rocks 676 and upper continental crust. Geochemistry, Geophysics, Geosystems. 2, 4, 2000GC000109.

677 https://doi.org/10.1029/2000gc000109

678 Mil-Homens, M., Caetano, M., Costa, A. M., Lebreiro, S., Richter, T., de Stigter, H., Johnson, M., 679 Branco, V., Cesario, R., Mouro, F., Mateus, M., Boer, W., Melo, Z., 2013. Temporal 680 evolution of lead isotope ratios in sediments of the Central Portuguese Margin: A fingerprint 681 of human activities. Marine Pollution Bulletin. 74, 1, 274-284. 682 https://doi.org/10.1016/j.marpolbul.2013.06.044

683 Mil-Homens, M., Vale, C., Brito, P., Naughton, F., Drago, T., Raimundo, J., Anes, B., Schmidt, S., 684 Caetano, M., 2017. Insights of $\mathrm{Pb}$ isotopic signature into the historical evolution and sources 685 of $\mathrm{Pb}$ contamination in a sediment core of the southwestern Iberian Atlantic shelf. Sci Total $686 \quad$ Environ. 586, 473-484. 
687 Monna, F., Hamer, K., Lévêque, J., Sauer, M., 2000. Pb isotopes as a reliable marker of early mining 688 and smelting in the Northern Harz province (Lower Saxony, Germany). Journal of 689 Geochemical Exploration. 68, 201-210. https://doi.org/10.1016/s0375-6742(00)00005-4

690 Nilsson, M., Klarqvist, M., Bohlin, E., et al., 2001. Variation in 14C age of macrofossils and different 691 fractions of minute peat samples dated by AMS. The Holocene 11, 579-586.

692 Novák, M., Emmanuel, S., Vile, M., Erel, Y., Véron, A., Pačes, T., Wieder, R.K., Vanecek, M., 693 Stepanova, M., Brizova, E., Hovorka, J., 2003. Origin of lead in eight European peat bogs 694 determined from isotope ratios, strengths, and operation times of regional pollution sources. 695 Environ. Sci.Technol. 37, 437-45. https://doi.org/10.1021/es0200387

696 Noryśkiewicz, A.M., 2004. Przemiany w szacie ro'slinnejokolic Us'cia w okresie ostatnich dwo' ch 697 tysie, cy lat. In W. Chudziak (Ed.), Wczesnos'redniowieczny zespo' ł osadniczy Kałdusie. 698 Studia przyrodniczo archeologiczne. 151-163.

699 Noryśkiewicz, A.M., 2005. Preliminary results of study on vegetation history in the Linje mire region 700 using pollen analysis. Monographiae Botanicae. 94, 118-133.

701 Pluskowski, A., 2013. The Archaeology of the Prussian Crusade: Holy War and colonization. 702 Routledge, Abington, UK. https://doi.org/10.4324/9780203079867

703 Reimann, C., Flem, B., Fabian, K., Birke, M., Ladenberger, A., Négrel, P., Demetriades, A., 704 Hoogewerff, J., The Gemas Project Team, 2012. Lead and lead isotopes in agricultural soils 705 of Europe - The continental perspective. Applied Geochemistry 27, 3, 532-542. https://doi.org/10.1016/j.apgeochem.2011.12.012 
707 Russell, R.D., Farquhar, R.M., 1960. Lead Isotopes in Geology. Interscience Publishers, New York.

708 Rybicka, E.H., 1996. Impact of mining and metallurgical industries on the environment in Poland.

709 Applied Geochemistry. 11, 3-9. https://doi.org/10.1016/0883-2927(95)00083-6

710 Samojlik, T.; Rotherham, I. D.; Jedrzejewska, B., 2013. Quantifying Historic Human Impacts on

711 Forest Environments: A Case Study in Bialowieza Forest, Poland. Environmental History.

$712 \quad$ 18, 3, 576-602. https://doi.org/10.1093/envhis/emt039

713 Schultz, M.F., Benjamin, M.M., Ferguson, J.F., 1987. Adsorption and desorption of metals on 714 ferrihydrite: reversibility of the reaction and sorption properties of the regenerated solid.

715 Environ. Sci. Technol. 21, 863-869. https://doi.org/10.1021/es00163a003

716 Shotyk, W., 1998. History of Atmospheric Lead Deposition since 12,370 14C yr. BP from a Peat

717 Bog, Jura Mountains, Switzerland. Science. 281, 5383, 1635-1640.

$718 \quad$ https://doi.org/10.1126/science.281.5383.1635

719 Szal, M., Kupryjanowicz, M. Wyczolkowski, M., Tylmann, W., 2014. The Iron Age in the Mrągowo 720 Lake District, Masuria, NE Poland : The Salet settlement microregion as an example of long721 lasting human impact on vegetation. Vegetation History and Archaeobotany. 23, 419-437.

722 Tessier, A., Fortin, D., Belzile, N., Dévitré, R.R., Leppard, G.G., 1996. Metal sorption to diagenetic 723 iron and manganese oxyhydroxides and associated organic matter: Narrowing the gap 724 between field and laboratory measurements. Geochimica et Cosmochimica Acta. 60, 3, 387725 404. https://doi.org/10.1016/0016-7037(95)00413-0 
726 Thevenon, F., Graham, N.D., Chiaradia, M., Arpagaus, P., Wildi, W., Pote, J., 2011. Local to regional 727 scale industrial heavy metal pollution recorded in sediments of large freshwater lakes in

728

729 central Europe (lakes Geneva and Lucerne) over the last centuries. Sci. Tot. Environ. 412413, 239-247. https://doi.org/10.1016/j.scitotenv.2011.09.025

730 Tranvik, L.J., Downing, J.A.., Carter, J.B., et al., 2009. Lakes and reservoirs as regulators of carbon 731 cycling and climate. Limnol. Oceanog. 54, 2298-2314.

732 Tyszka, R., Pietranik, a., Kierczak, J., Ettler, V., Mihaljevič, M., Weber, J., 2012. Anthropogenic and 733 lithogenic sources of lead in Lower Silesia (Southwest Poland): An isotope study of soils, 734 basement rocks and anthropogenic materials. Applied Geochemistry. 27, 6, 1089-1100. 735 https://doi.org/10.1016/j.apgeochem.2012.02.034

736 Urban, W., 1980. The Prussian Crusade. University Press of America, Inc. London, England.

737 Verner, J.F., Ramsey, M.H., Helios-Rybicka, E., Jedrzejczyk, B., 1996. Heavy metal contamination 738 of soils around a Pb-Zn smelter in Bukowno, Poland. Applied Geochemistry. 11, 11-16. 739 https://doi.org/10.1016/0883-2927(95)00093-3.

740 Véron, A., Novak, M., Brizova, E., Stepanova, M., 2014. Environmental imprints of climate changes 741 and anthropogenic activities in the Ore Mountains of Bohemia (Central Europe) since 13 cal.

742 Kyr. BP. The Holocene. 24, 8, 919-931. https://doi.org/10.1177/0959683614534746

743 Wentworth, C.K., 1922. A scale of grade and class terms for clastic sediments. The Journal of 744 Geology. 30, 5, 377-392. https://jstor.org/stable/30063207 
745 Zaborska, A., 2014. Anthropogenic lead concentrations and sources in Baltic Sea sediments based 746 on lead isotopic composition. Marine Pollution Bulletin. 85, 1, 99-113. $747 \quad$ https://doi.org/10.1016/j.marpolbul.2014.06.013

748 Zamoyski, A., 1987. The Polish Way: A thousand year history of the poles and their culture. John 749 Murray Ltd, Great Britain.

750 Zhou, A., Yuxin, H., Shang, X., et al., 2015. Changes in the radiocarbon reservoir age in Lake 751 Xingyun, southwestern China during the Holocene. PLoS One 10, 1-21.

752 Zillen, L., Lenz, C., Jilbert, T., 2012. Stable lead (Pb) isotopes and concentrations - A useful 753 independent dating tool for Baltic Sea sediments. Quaternary Geology. 8, 41-45. $754 \quad$ https://doi.org/10.1016/j.quageo.2011.11.001

755 Zohar, I., Bookman, R., Levin, N., de Stigter., H., Teutsch, N., 2014. Contamination History of Lead 756 and Other Trace Metals Reconstructed from an Urban Winter Pond in the Eastern 757 Mediterranean Coast (Israel). Environ. Sci. Technol. 48, 13592-13600. https://doi.org/10.1021/es500530x 


\section{Click here to download Figure: Figures.pdf}
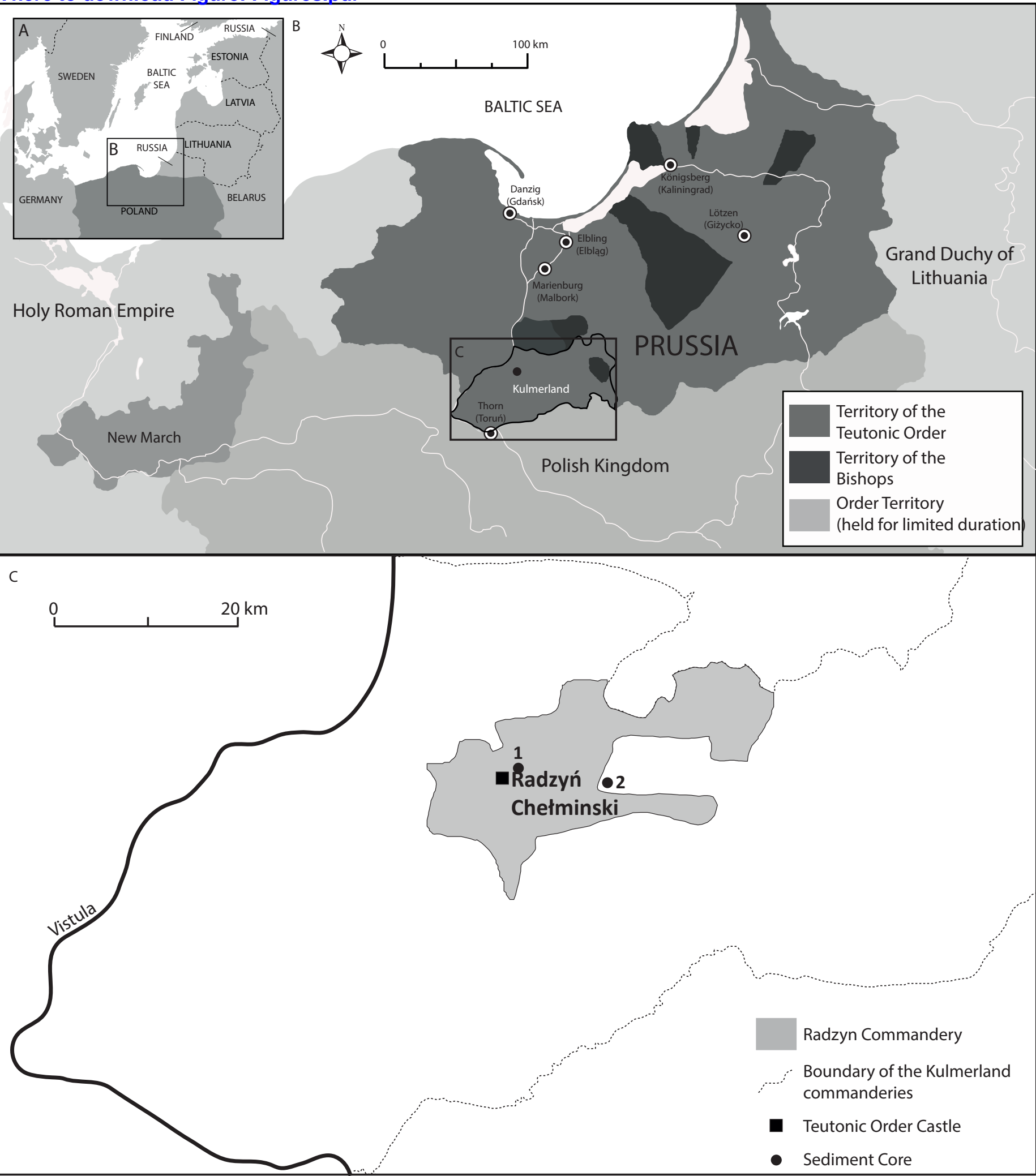

Figure 1 


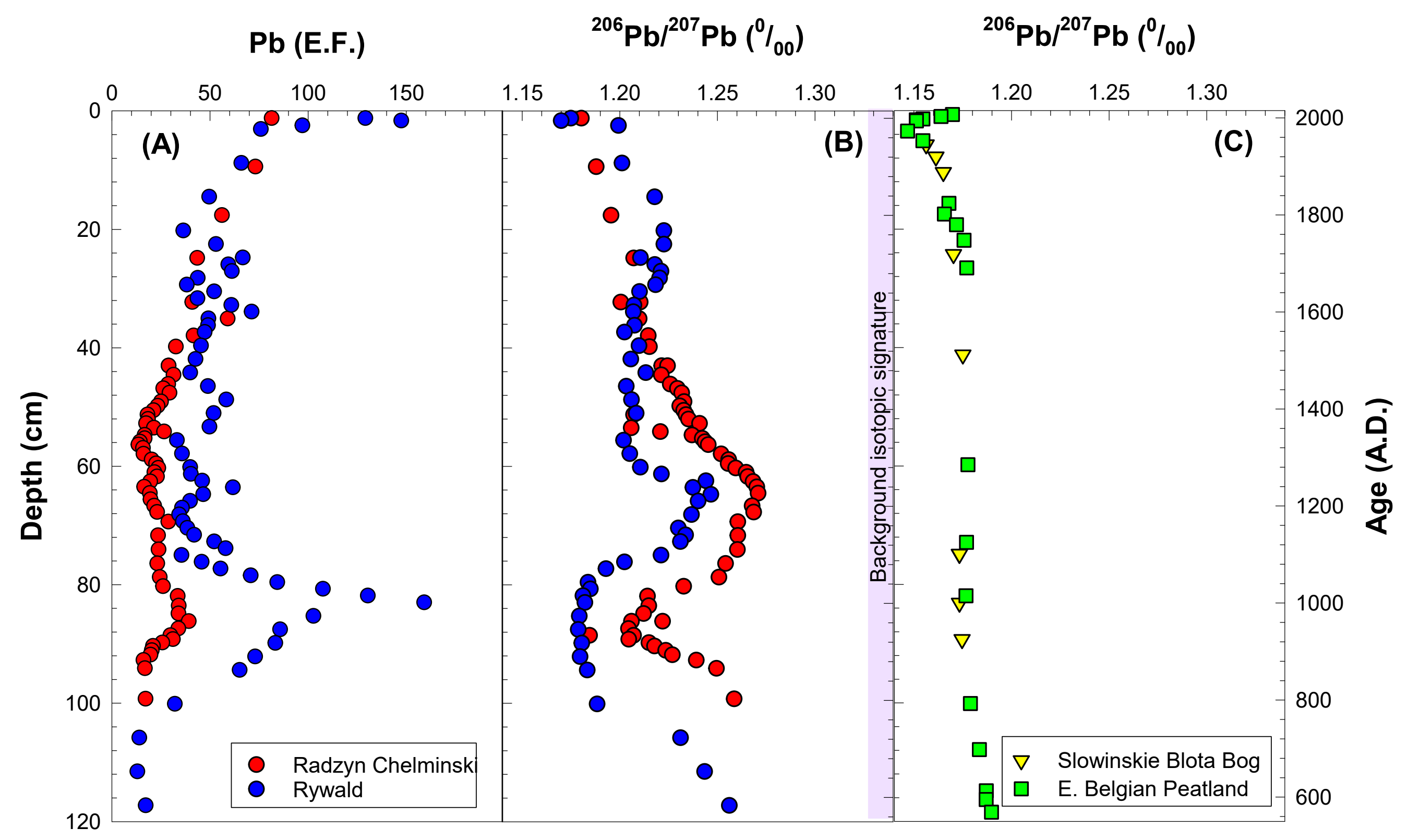




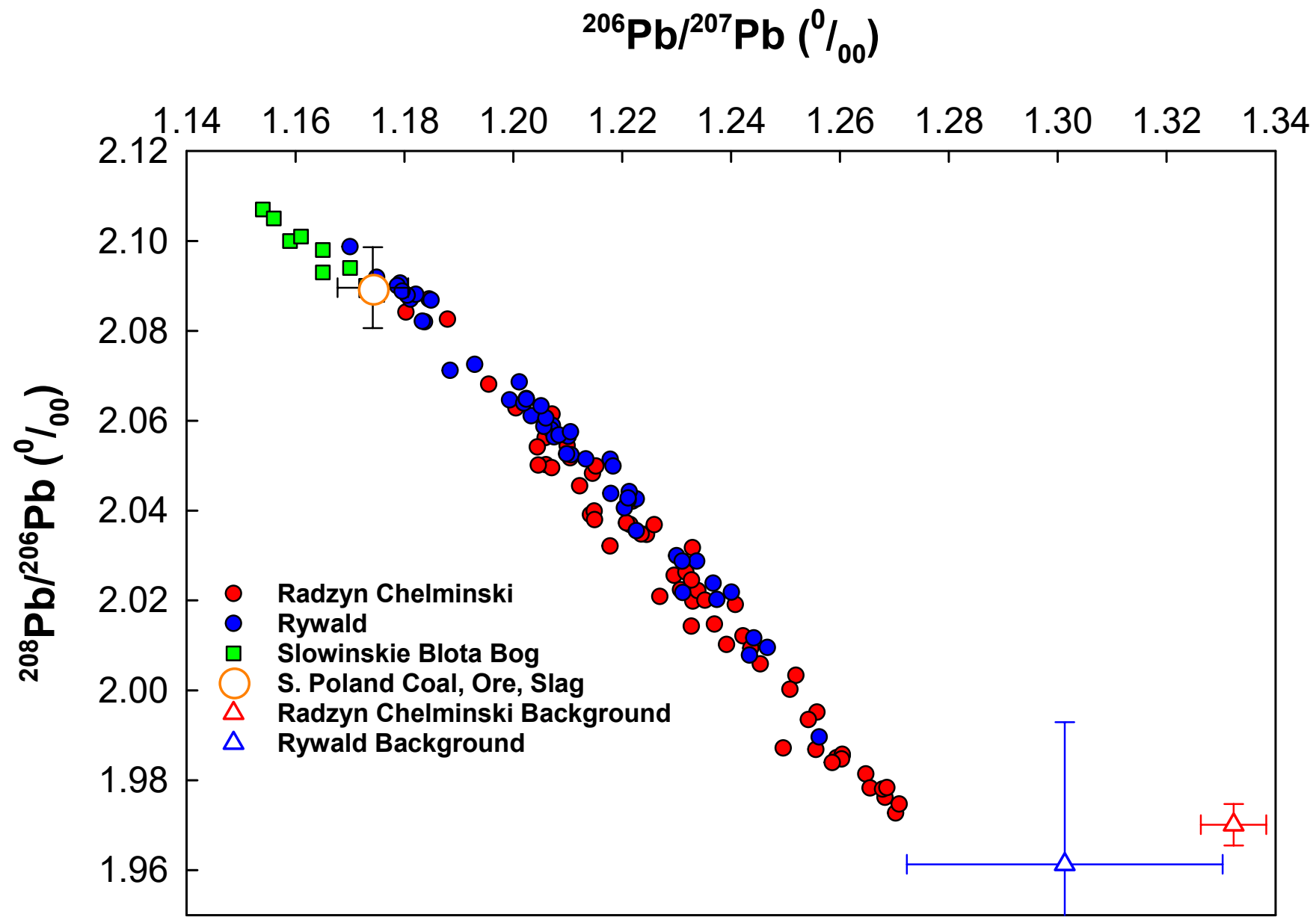

Figure 3 

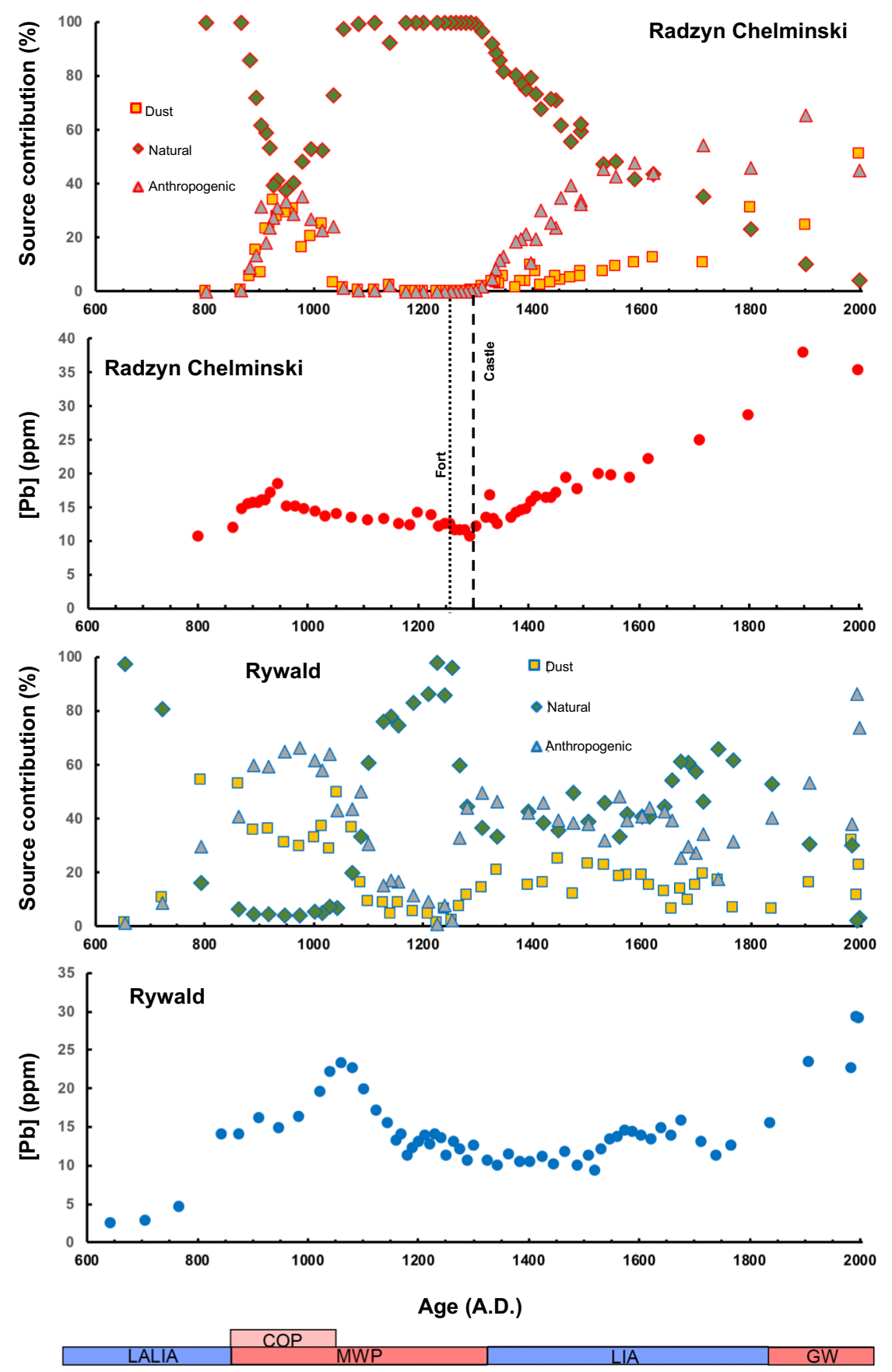


\section{Figure captions}

Figure 1: Site Map. A) Central and Eastern Europe, B) Location of the Kulmerland within Medieval Prussia, including lands controlled by the Teutonic Order, C) The Kulmerland region including (1) Radzyń Chełmiński core, Radzyń Chełmiński Castle, and (2) Rywałd core (modified from Brown et al., 2015).

Figure 2: Sedimentary profiles of $\mathrm{Pb}$ enrichment factors (E.F., left panel), ${ }^{206} \mathrm{~Pb} /{ }^{207} \mathrm{~Pb}$ (\%o) isotopic ratios for Radzyń Chełmiński and Rywałd (middle panel, the vertical light purple represents the ${ }^{206} \mathrm{~Pb} /{ }^{207} \mathrm{~Pb}$ isotopic signature of the background, i.e. underneath earth material layer), and previously published profiles (right panel) from a bog located in Northern Poland (De Vleeschower et al., 2009) and a Belgian Peatland (Fagel et al., 2014).

Figure 3: ${ }^{206} \mathrm{~Pb} /{ }^{207} \mathrm{~Pb}$ and ${ }^{208} \mathrm{~Pb} /{ }^{206} \mathrm{~Pb}$ isotopic ratio three-point plot. Red dots, blue dots, green squares, open orange circle, open red triangle and open blue triangle represent Radzyń Chełmiński, Rywałd, Slowinskie Blota Bog (De Vleeschower et al., 2009), Poland ore, slag, coal (Tyszka et al., 2012), Radzyń Chełmiński background and Rywałd background, respectively.

Figure 4: Source contribution -dust, natural and anthropogenic-(top panel for Radzyń Chełmiński and third panel for Rywałd) and $\mathrm{Pb}$ concentration (second panel for Radzyń Chełmiński and bottom panel for Rywałd) versus time (horizontal bottom axis). Source contribution was calculated 
using a Bayesian code (FRUITS) using ${ }^{206} \mathrm{~Pb} /{ }^{207} \mathrm{~Pb} \%$ and ${ }^{208} \mathrm{~Pb} /{ }^{206} \mathrm{~Pb} \%$. See main text for detailed explanation about the modeling. Horizontal bars (blue and red) below the plot displays climatic periods. Late Antique Little Ice Age (LALIA, 536 to 660 AD; left blue bar). Climatic Optimum in Prussia (COP, 800 to 1150 AD; light red bar on the top). Medieval Warm Period (MWP; 800 to 1300 AD; left red bar). Little Ice Age (LIA; 1300 to 1850 AD; right blue bar). Global Warming (GW; 1890 to present; right red bar). Vertical arrows are only relevant to Radzyń Chełmiński and represent the Teutonic timber fort built (1234 AD; Urban, 1980) and the Radzyń Chełmiński Castle Built (late $13^{\text {th }}$ century; Urban, 1980), respectively. 
Supplementary material for on-line publication only
Click here to download Supplementary material for on-line publication only: Supplementary_Info.pdf

Supplementary material for on-line publication only
Click here to download Supplementary material for on-line publication only: Supplementary_Info.pdf

Supplementary material for on-line publication only
Click here to download Supplementary material for on-line publication only: Supplementary_Info.pdf

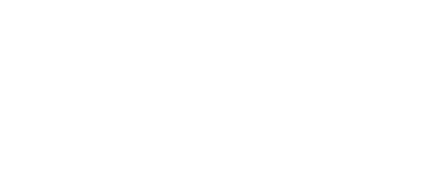

(1)

(1)

(1)

.

.

.

.

.

.

.

.

.

.

.

.

.

.

.

.

.

.

.

.

.

.

.

.

.

.

. 